\title{
FRESHWATER MICRO-GASTROPODS FROM THE IGUAÇU NATIONAL PARK, BRAZIL: TWO NEW TRUNCATELLOID CAENOGASTROPODS AND ANATOMY OF CHILINA MEGASTOMA HYLTON SCOTT, 1958 (GASTROPODA: HYGROPHILA: CHILINIDAE)
}

\author{
LUIZ RICARDO L. SIMONE
}

\begin{abstract}
Museu de Zoologia da Universidade de São Paulo, Cx. Postal 42494, 04218-970, São Paulo, SP, Brazil (e-mail: lrsimone@usp.br; lrlsimone@gmail.com); (1) https://orcid.org/0000-0002-1397-9823
\end{abstract}

\begin{abstract}
Collecting in Foz do Iguaçu National Park, Paraná, Brazil, an important tourist region with preserved rainforest, has revealed three micro-gastropod species which required morphological and taxonomic studies. One of them is a chilinid Chilina megastoma Hylton Scott, a member of a poorly studied group. Another two are new species of truncatelloid caenogastropods: Potamolithus mirim n. sp. and Heleobia iguassu n. sp. The three species are described in detail and discussed from taxonomic and phylogenetic point of view. As they are highly endemic, protective measures are suggested.
\end{abstract}

KEY WORDS: Mollusca; systematics; morphology; taxonomy

\section{INTRODUCTION}

Parque Nacional do Iguaçu, in Paraná, Brazil, is an important tourist attraction of the country. Being a national park, the area is protected from exploitation, except for the famous waterfalls and the surrounding commercial area. The park has its counterpart in Argentina, called Iguazú. Besides the rich freshwater formations, such as rivers and waterfalls, the area of ca. $1,700 \mathrm{~km}^{2}$ holds a luxuriant well-preserved fragment of Atlantic Rainforest (SALAMUNI et al. 2001, BRITO 2014).

A paper containing a complete list of Iguaçu malacofauna is in preparation; this contribution focuses on some freshwater micro-gastropods found in a fountain located close to the trail which leads to the main waterfalls (OvANDO et al. 2020: fig. 1B). The fountain is ca. $1 \mathrm{~m}^{2}$ in area. Four species of minute gastropods were collected from submerged leaves and leaf litter. One of them was a known pulmonate species - Chilina megastoma Hylton Scott, 1958 - Chilinidae, a family endemic to South America, with about 60 species mostly occurring east of the
Andes (ITUARTE 1997, Simone 2006a, GutiérRez GREGORIC \& RUMI 2008, GUTIÉRREZ GREGORIC \& DE LUCÍA 2016). The Chilinidae comprise a single genus - Chilina Gray, 1828 (type species Bulimus dombeianus Bruguiére, 1789) with about 50 species. With the Latiidae, they form the Hygrophila superfamily Chilinoidea (BOUCHET \& ROCROI 2005, WoRMS 2020). Papers describing anatomical features of the Chilinidae are few, some are part of more comprehensive publications on pulmonates (e.g., DUNCAN 1960), or focus on certain details, for example radula, genital system and nerve ring (e.g., ITUARTE 1997, GUTIÉRREZ GREGORIC \& RUMI 2008, OVANDO \& GuTIÉRREZ GREGORIC 2012, GUTIÉRREZ GREGORIC \& DE LUCÍA 2016). More holistic approaches to the chilinid morpho-anatomy are even fewer (HAECKEL 1911, HARRY 1964, BRACE 1983). The new information is included here as part of a wider project which is aimed at understanding the heterobranch evolutionary pathways as confronted with molecular approaches (e.g., KoCH et al. 2015), and at provid- 
ing new and interesting data. Another collected pulmonate was the planorbid Acrorbis petricola Odhner, 1937, represented by a single specimen; as the species is relatively well known with respect to its anatomy and taxonomy, it is not discussed here.

The other group described here comprises two new species of caenogastropod Rissooidea (sensu SIMONE 2006b, 2011), or Truncatelloidea (sensu PONDER 1988) (see Discussion). One of them represents the genus Potamolithus Pilsbry, 1896 (type species Paludina lapidum d'Orbigny, 1835), Tateidae. The genus is endemic to the southern half of South America, and comprises about 50 species (SIMONE \& Moracchioli 1994, BichueTte \& TRAJANO 2018, Cuezzo et al. 2020). The other species is a mem-

\section{MATERIAL AND METHODS}

Special permissions are required to collect in Parque Nacional do Iguaçu; such permission were obtained accordingly (licenses IBAMA-Sisbio 617071 and 73226-1).

The specimens were collected and fixed in $70 \%$ $\mathrm{ETOH}$, they were examined with standard techniques, with the specimens dissected immersed in alcohol; the specimens were extracted from their shells which were crushed, all dissection steps were photographed and some structures were processed for serial sections (SIMONE 2011). All drawings were made with the aid of a camera lucida; the drawings combine the averaged data of several specimens.

In the figures, the following abbreviations are used: aa - anterior aorta, ac - albumen chamber, ad - albumen gland duct, af - anal furrow, ag - albumen gland, an - anus, ap - penial aperture, ar - adrectal sinus, as - visceral (abdominal) ganglion, au - auricle, bc - bursa copulatrix, bd - bursa duct, bg - buccal ganglion, br - subradular cartilage, cc - cerebral commissure, ce - cerebral ganglion, cg - capsule gland, $\mathrm{cm}$ - columellar muscle, $\mathrm{cv}$ - ctenidial/pulmonary (efferent) vein, dd - duct of digestive gland, df - dorsal fold of buccal cavity, dg - digestive gland, di - diaphragm or pallial cavity floor, $\mathrm{dv}$ - diverticulum, eg - oesophageal gland, eo - spermoviduct, es - oesophagus, ey - eye, fe - faecal pellet, fl - flap ventral to pneumostome, fo - free oviduct, fp - female gonopore, fs - foot sole, ber of Heleobia Stimpson, 1865 (type species Paludina culminea d'Orbigny, 1835) (HERSHLER \& THOMPSON 1992, KabAT \& HERSHLER 1993, KoCH et al 2015), Cochliopidae, a complex genus with ca. 40 species, mostly occurring in the Andean region, but with some species scattered in several South American basins (HERSHLER \& THOMPSON 1992). Both genera include highly endemic species, and the two species described hitherto from the area attract attention due to their minute size, compared to their congeners.

The aim of this paper is to provide detailed descriptions of the three species of micro-gastropods from the Iguaçu Park, with a discussion of their taxonomic position. Formal descriptions of the two new species are presented.

$\mathrm{ft}$ - foot, gf - genital furrow, gi - gill, gm - gizzard muscular piston, go - gonad, gp - pedal ganglion, gz - gizzard, ha - haemocoel, hd - hermaphrodite duct, he - head, hm - head retractor muscle, in - intestine, jw - jaw, ki - kidney, m1-m10 - extrinsic and intrinsic odontophore muscles, $\mathrm{mb}$ - mantle border, $\mathrm{mj}$ - peribuccal muscles, $\mathrm{mn}$ - mantle connection with nuchal region, mo - mouth, mr - retractor muscle of buccal mass, ne - nephrostome, $\mathrm{nr}$ - nerve ring, oc - odontophore cartilage, od - odontophore, op - operculum, os - osphradium, ot - oral tube, ov - pallial oviduct, oy - ovary, pa - penial appendix, pc - pericardium, $\mathrm{pd}-$ penis duct, pe - penis, pg - anterior furrow of pedal gland, pi - penis papilla, $\mathrm{pl}$ - pallial muscle, $\mathrm{pm}$ - penial muscle, pn - pneumostome, po - posterior aorta, pp - pleural ganglion, $\mathrm{pt}$ - prostate, ra - radula, rn - radular nucleus, rs - radular sac, rt - rectum, sa - salivary gland aperture, sd - salivary duct, sg - salivary gland, sn - snout, sr - seminal receptacle, ss style sac, st - stomach, su - subintestinal ganglion, sv - seminal vesicle, ta - terminal genital atrium, te - cephalic tentacle or flap, uf - ureteral furrow, ur - ureter, ut - uterus, va - vas deferens aperture, vd - vas deferens, ve - ventricle, vg - vagina, vo - visceral oviduct

Institutional abbreviations: MNRJ - Museu Nacional da Universidade Federal do Rio de Janeiro, MPL - Museo de La Plata, Argentina, MZSP - Museu de Zoologia da Universidade de São Paulo, Brazil. 


\section{Subclass Heterobranchia}

\section{Family Chilinidae}

\section{Chilina megastoma Hylton Scott, 1958}

(Figs 1-26)

Chilina megastoma SCOTT 1958:26-27, figs 1-2; ITUARTE 1997: 9-15, figs 1-26); GUTIÉRREZ GREGORIC \& RUMI 2008: 321-329, fig. 8; GUTIÉRREZ GREGORIC et al. 2010: 159-164, figs 2-4, 2012: 109, 115; GUTIÉRREZ GREGORIC \& DE LUCÍA 2016: 1-21; OvANDO et al. 2020: 21-22, fig. 2.

Type locality. Cataratas del Iguazú. Misiones, Argentina.

Type material. Museo de La Plata, Argentina. Holotype (unnumbered) (14.9 by $12.4 \mathrm{~mm}$ ) (Figs 1-2); 2 paratypes (Fig. 3) (not mentioned in original description).

\section{COMPLEMENTARY DESCRIPTION}

Shell (Figs 1-7). Shell height up to $17 \mathrm{~mm}$. Colour uniformly dark reddish brown, with no pattern. Sculpture of pronounced growth lines and minute, shallow striae, ca. 53 on body whorl, rather regularly spaced (Figs 2, 5, 6). Aperture ca. $85 \%$ of shell height, ca. $70 \%$ of shell width (Figs 1, 3, 4). Inner lip sinuous, upper third as thin, obsolete callus; lower $2 / 3$ concave, widening downward as white, glossy lip; pair of low, transverse, well-spaced teeth located between upper and middle thirds. For other details see SCOTT (1958) and ITUARTE (1997).

Head-foot (Figs 10, 11, 15, 23). Exposed areas brown pigmented, tentacles and foot with pale edges. Head flat, head-foot boundary poorly marked. Tentacles (te) in the form of wide, short flaps, their edges slightly rounded, each ca. $1 / 3$ of head width; space between them equal to tentacle width. Eyes (ey) minute, located in mid-region of tentacles, closer to their base; immersed in integument. Foot (ft) simple, stubby, ca. $2 / 3$ whorl in length; its anterior edge slightly bi-lobed, with mouth (mo) between lobes. Genital furrow (Fig. 11: gf) Y-shaped, only on right side; posterior branch connecting female and male gonopores, along ca. $65 \%$ of foot length; anterior branch short, running to base of right tentacle; interior branch short, running ventrally close to foot edge. Haemocoel (ha) occupying ca. $60 \%$ of headfoot volume, dorsal integument as poorly muscled diaphragm (Fig. 10: di); ventral surface as wide pair of head retractor muscles (Fig. 15: hm), and columellar muscle $(\mathrm{cm})$ (for more details see below); tapering posteriorly and curved to the right, ventrally covering anterior end of visceral mass.
Mantle organs (Figs 10, 12). Mantle edge (mb) thick, unpigmented. Pneumostome lacking sphincter or discernible adjacent muscles, ca. 1/3 length of dorsal mantle edge (Fig. 10: pn); both ends with short furrows at an angle to the edge: faecal furrow on the right (af), urinary furrow on the left (uf). Lung occupying ca. $70 \%$ of body whorl (Fig. 10), roughly rectangular; no visible network of vessels except for relatively strong transverse kidney folds (Fig. 10: ki). No detectable gill. Pulmonary vein (Figs 10, 12: cv) well-developed, flanking left margin of kidney, becoming gradually wider posteriorly, extending to auricle. Kidney flattened, in approximately central position, occupying ca. half of pallial roof (for details see below), pericardium size ca. $30 \%$ of renal area, located in posterior right corner of cavity (for details see below). Rectum (rt) running all along cavity, on its right margin; emerging in cavity only in its posterior $1 / 4$, remainder covered by thick adrectal sinus (ar). Anus (an) sessile, located in anterior right corner of cavity, on the right side of pneumostome. Pallial muscle well developed, mainly in posterior region (Fig. 10: pl), appearing gradually on right margin of pallial cavity from anterior to posterior, becoming thicker toward posterior right corner of cavity, inserting on columella just posterior to columellar muscle $(\mathrm{cm})$, inside anterior end of visceral mass.

Visceral mass (Figs 10, 13). Relatively small, its size ca. half that of pallial cavity; 2 whorls long, mostly filled by greenish-beige single-lobed digestive gland (dg). Gonad (go) whitish, lying along middle of columellar surface. Midgut located in anterior half whorl (Fig. 13), as widely sigmoid intestinal loop (in) immersed in digestive gland, with duct of digestive gland (dd). For more details see below.

Circulatory and excretory systems (Figs 10, 12). Pericardium ca. three times longer than wide, located in posterior left corner of pallial cavity (pc); occupying ca. $5 \%$ of cavity. Auricle located anteriorly (au) as continuation of pulmonary vein (cv), twice as long as ventricle; walls thin, translucent (au). Ventricle thickwalled, anteriorly connected with auricle, posteriorly connected with aorta trunk (ve). Anterior aorta (Fig. 13: aa) running posteriorly, dorsally surrounding intestine. Kidney size reported above; kidney simple, entirely solid (ki), with two lobes separated by longitudinal vessel; right lobe twice as large as left lobe; both with several transverse, branched folds; anterior third narrow, with both lobes of equal width. Nephrostome (ne) as papilla located subterminally, in anterior edge of kidney, at base of urinary furrow (uf). Digestive system (Figs 13-14, 16-18, 21). Oral tube (ot) long and narrow, piercing foot integument to reach small, rounded mouth located ventrally, be- 
tween head and foot (Figs 11, 15: mo); nerve ring located anterior to buccal mass (Figs 13-14: nr). Buccal mass spherical, ca. 1/3 of haemocoel volume (Fig. 13). Oral cavity relatively narrow (Fig. 16). Jaws absent. Pair of well-developed dorsal folds of buccal mass (Fig. 16: df) occupying most of dorsal surface of oral cavity; space between dorsal folds relatively narrow and shallow; on each dorsal fold small me-

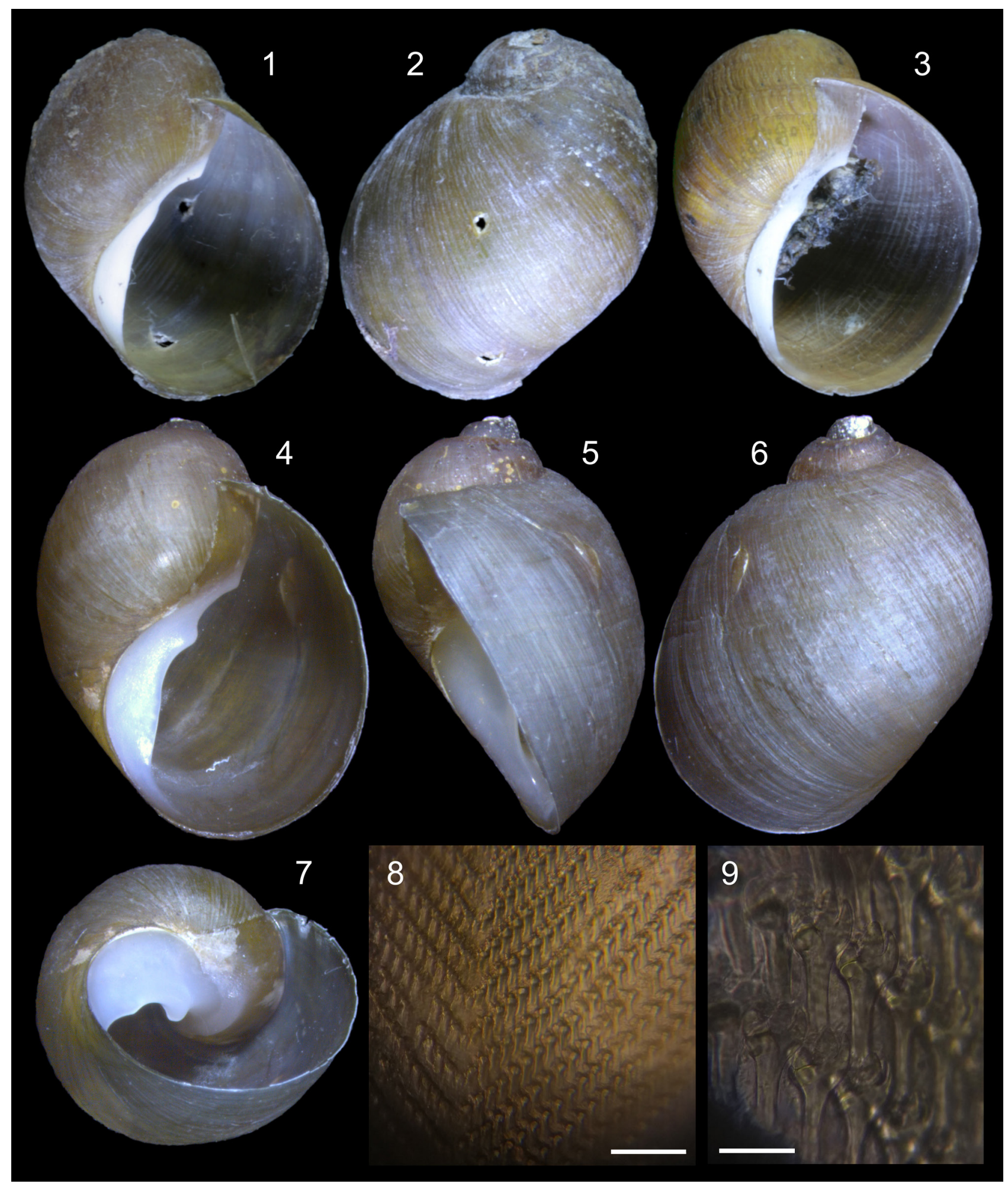

Figs 1-9. Chilina megastoma shell and radula: 1-2 - holotype MLP, frontal and dorsal views (shell height $14.9 \mathrm{~mm}$ ), 3 paratype MLP, frontal view (shell height $18.7 \mathrm{~mm}$ ), 4-7 - MZSP 151286, frontal, lateral right, dorsal and umbilical views (shell height $10.3 \mathrm{~mm}$ ), 8 - radula, central region, scale bar $0.1 \mathrm{~mm}, 9$ - radula, detail of central region of lateral teeth, scale bar $200 \mu \mathrm{m}$ 


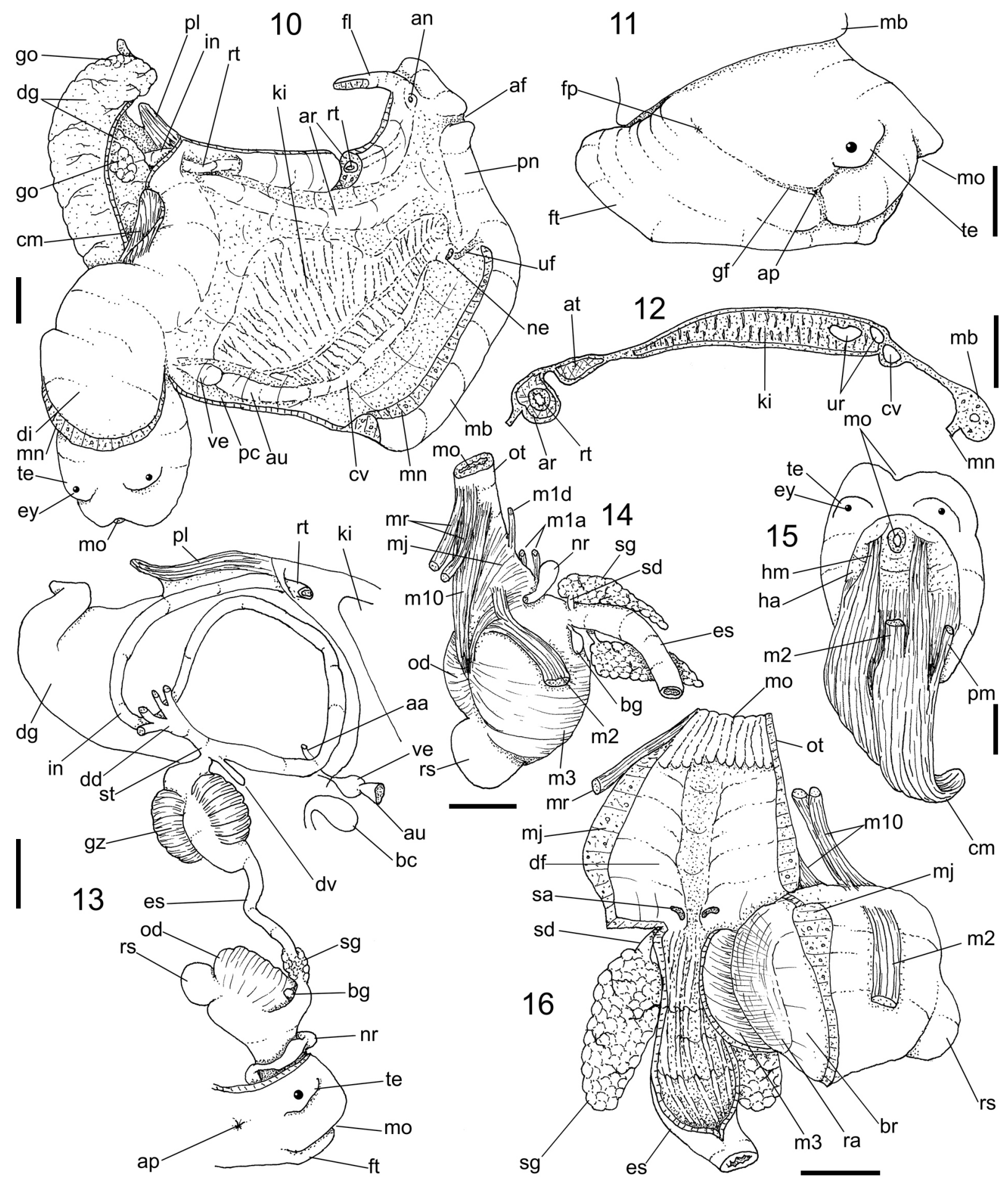

Figs 10-16. Chilina megastoma anatomy: 10 - whole dissected specimen, pallial cavity sectioned and deflected, visceral mass slightly uncoiled, transverse section at mid-level of rectum shown, 11 - head-foot, lateral right view, 12 - pallial cavity roof, transverse section at mid-level, 13 - digestive tubes as in situ (foregut lateral right view, midgut ventral view), topology of some adjacent structures also shown, 14 - foregut, left-ventral view, 15 - head and haemocel, dorsal view, inner structures and dorsal integument removed, 16 - foregut opened longitudinally, odontophore deflected to right. Scale bars $1 \mathrm{~mm}$. For abbreviations see text p. 14 
dial aperture anterior to oesophageal entrance, corresponding to outlet of salivary duct (Fig. 16: sa). Odontophore and peri-oral muscles (Figs 14, 16-18): $\mathrm{mr}$ - pair of buccal retractor muscles, originating in middle of ventral wall of haemocoel, running anteriorly, inserting on ventral side of mouth (Fig. 14: $\mathrm{mr}$ ); $\mathbf{m j}$ - pair of peribuccal muscles (Figs 14, 16, 18) fairly thick, inserted on both sides of odontophore cartilages (oc) (Fig. 18), extending along entire buccal cavity dorsalward as layer of circular fibres (Fig. 14); mla - narrow pair of dorsal median protractor jugal muscles of buccal mass (Fig. 14), originating on dorsal surface of haemocoel at level just posterior to mouth, running posteriorly close to median line, inserting in dorsal region of buccal mass at end of oral tube; m1d - additional pair of dorsal median protractor jugal muscles of buccal mass, similar to mla but inserted more posteriorly, at mid-level of odontophore (Fig. 14), m2 - pair of buccal mass retractor muscles (or radular muscle), originating in middle of lateral wall of haemocoel and also in mid-region of columellar muscle (Fig. 15: m2), running ventrally and anteriorly, their insertions spreading in lateral wall of oral tube (Fig. 14) and their part, penetrating
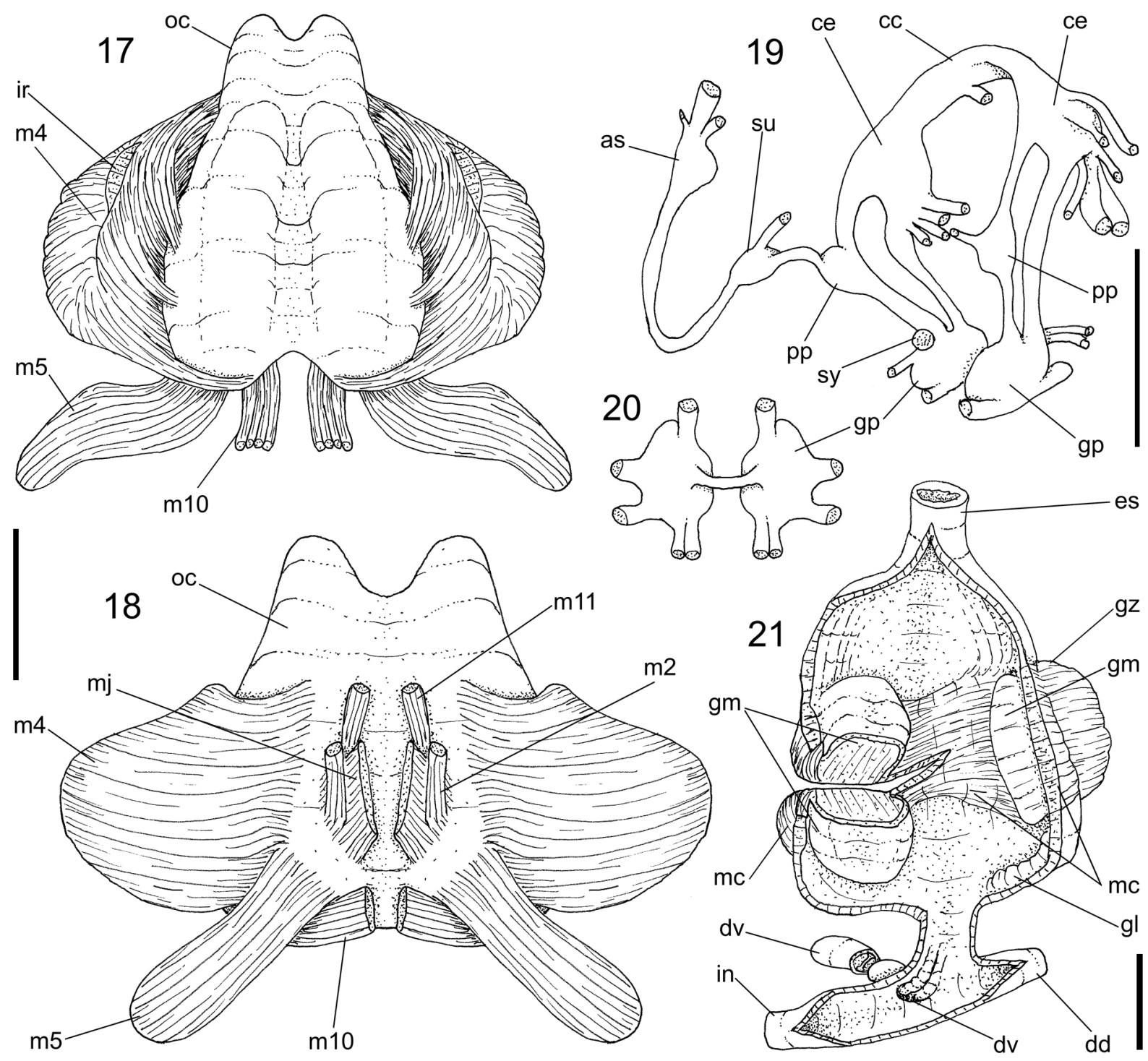

Figs 17-21. Chilina megastoma anatomy: 17 - odontophore, dorsal view, superficial layer of structures removed, muscles deflected, 18 - same, ventral view, 19 - central nervous system (nerve ring), posterior-right view, 20 - detail of pair of pedal ganglia, ventral view (same scale), 21 - oesophagus and midgut mostly opened longitudinally, ventral view, gizzard (gz) partially sectioned transversally to show its muscular system, same for diverticulum (dv). Scale bars $1 \mathrm{~mm}$. For abbreviations see text p. 14 
into odontophore, inserted in posterior region of odontophore cartilages, on their middle outer surface, close to mj (Fig. 18); m3 - single transverse thin muscle layer covering region between odontophore and oesophagus (Figs 14, 16: m3); m4 - main pair of dorsal tensor muscles of radula (Figs 17, 18), thick, originating in lateral and latero-dorsal regions of odontophore cartilages (oc), with at least three equidistant folds (Fig. 17), surrounding cartilages anteriorly and medially; inserting in radular sac (ir) along its region immediately posterior to buccal cavity (Fig. 17); $\mathrm{m} 5$ - pair of thin and narrow auxiliary dorsal tensor muscles (Figs 17-18), originating on outer-posteri- or surface of cartilages, covering m4 (Fig. 18), running medially and anteriorly; inserting in radular sac just ventral to $\mathrm{m} 4$ insertion; $\mathrm{m} 6$ - horizontal muscle absent; m10 - pair of ventral protractor muscles of buccal mass (Figs 14, 16), originating in ventral and lateral region of mouth (Fig. 14), running posteriorly, tapering gradually close to median line, inserting in ventro-median region of odontophore cartilage (Fig. 18: $\mathrm{m} 10)$, close to region of radular sac; $\mathrm{m} 11$ - pair of narrow ventral tensor muscles of radula (Fig. 18), originating in mid-ventral surface of odontophore cartilages, running anteriorly, inserting in ventral end of subradular cartilage (br). Odontophore

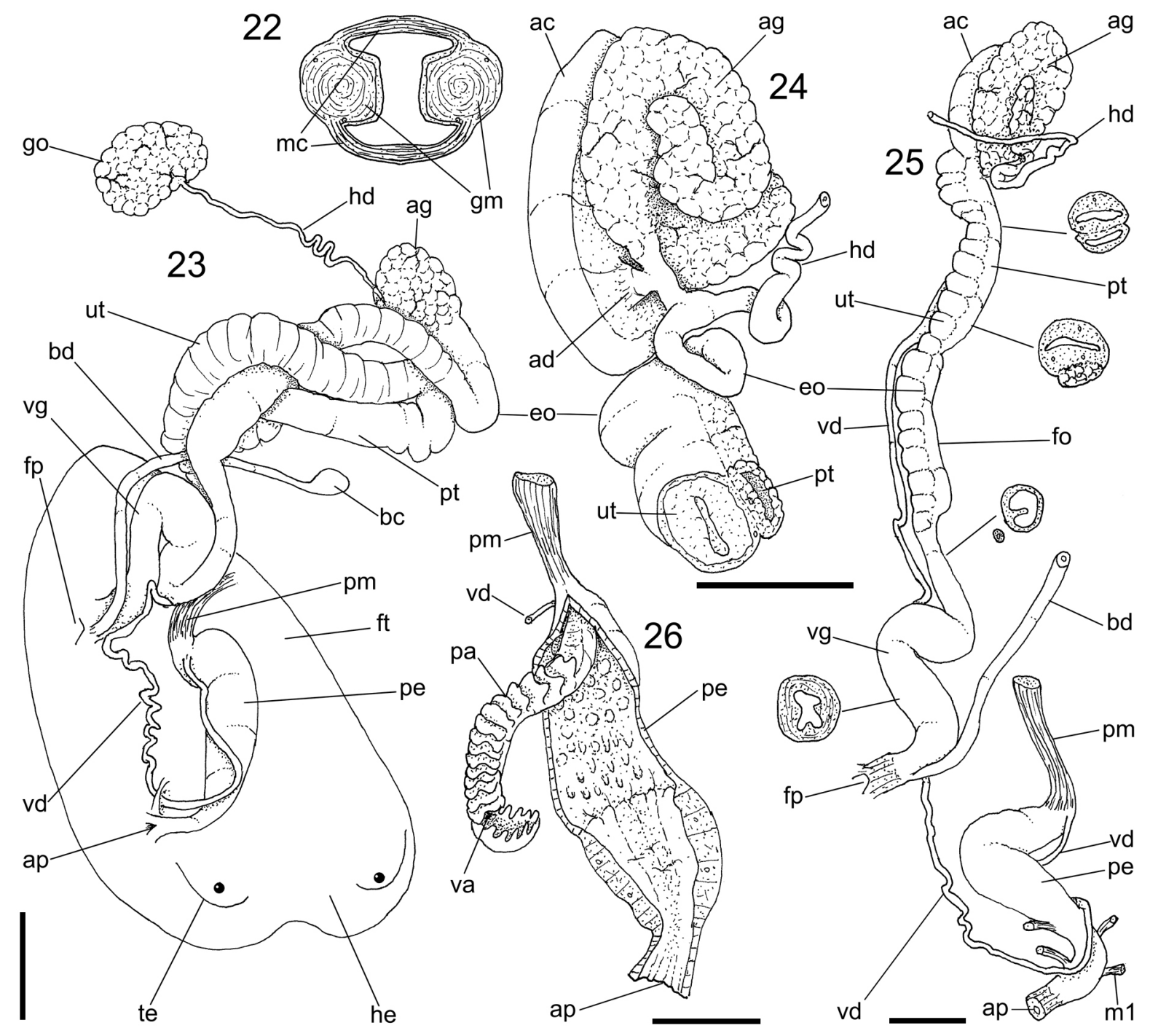

Figs 22-26. Chilina megastoma anatomy: 22 - gizzard, schematic representation of transverse section, 23 - genital structures as in situ, mostly in dorsal view, topology of head-foot shown, 24 - detail of carrefour region, ventral view, both ends sectioned transversally, 25 - uncoiled genital structures (except gonad), mostly in dorsal view, transverse sections at indicated levels also shown, 26 - penis opened longitudinally, dorsal view, penial appendix (pa) uncoiled and deflected. Scale bars $1 \mathrm{~mm}$. For abbreviations see text p. 14 
non-muscular structures: oc - odontophore cartilages, flattened, claviform, almost entirely fused with each other along median line (Figs 17-18), except for both ends; anterior end of each cartilage roughly rounded, about half width of posterior end; br - subradular cartilage, with expanding region in buccal cavity protecting subradular membrane (Fig. 16).

Radula. Slightly longer than odontophore (Figs 14, 16). Radular (Figs 8-9) rows at an angle of ca. $90^{\circ}$ to rachidian. Rachidian narrow, ca. 3 times longer than wide, claviform, lacking cusps. About 40 pairs of lateral-marginal teeth, without clear distinction between both, except for gradual and uniform narrowing in lateral direction. Each lateral tooth also claviform, with narrow middle stem (ca. 4-times longer than wide), and abruptly expanding apex with three marginal cusps; two lateral cusps bluntly pointed; more medial cusp stubby, smaller, with rounded tip. Salivary glands covering anterior end of oesophagus (Figs 14, 16: sg), as two white, thin masses. Pair of salivary ducts distinguishable anteriorly, close to region of penetration in latero-posterior region of buccal mass (Fig. 14: sd). Salivary ducts running short distance immersed in dorsal wall of buccal mass; opening as described above on edges of postero-median dorsal folds (Fig. 16: sa). Oesophagus ca. 80\% of haemocoel length, walls thin, relatively rigid; its anterior half narrow (Fig. 13: es); on its inner surface 8-10 longitudinal, narrow folds, as continuation of buccal cavity dorsal folds (Fig. 16: es). Posterior half of oesophagus greatly enlarged as gizzard (Fig. 13: gz). Gizzard highly muscular in its mid-region, with pair of opposite muscular pistons, inner surface covered by conchiolin, with opposite surfaces flattened (Figs 21, 22: gm), remainder rounded; both pistons united externally by thick circular muscular belt (Figs 21, 22: mc). Oesophageal region tapered anterior and posterior to muscular apparatus of gizzard, inner surface smooth, except for short longitudinal glandular fold on one side of distal portion (Fig. 21: $\mathrm{gl}$ ). Behind gizzard short narrow portion of oesophagus opening in T-fashion into minute stomach (st). Stomach marked only by large duct of digestive gland (Figs 13, 21: dd) posteriorly and intestinal origin (in) anteriorly. Small diverticulum, ca. half as wide as intestine, inserted between oesophageal insertion and intestinal origin (Figs 13, 21: dv); its inner surface highly glandular, lumen flattened (Fig. 21). Intestine narrow, performing 2 wide loops as shown in Fig. 13 (in). Rectum narrow (rt); for anus (an) see above.

Genital system (Figs 23-26). Mostly located along right side of haemocoel, running from visceral mass close to columella; occupying ca. 1/4 of haemocoel volume. Gonad described above (visceral mass). Hermaphrodite duct (Fig. 23: hd) narrow, weakly coiled; running along ca. $1 / 2$ whorl; inserting in spermoviduct next to albumen duct (Fig. 24: hd).
Seminal receptacle absent. Albumen gland mostly slightly smaller than gonad, its outline spherical (Fig. 25: ag), but composed of tapering spiral of ca. 2 solid whorls (Fig. 24: ag), located in posterior end of haemocoel (Fig. 23: ag). Albumen chamber almost as long as albumen gland, flattened, located next to it, posterior to gland (Figs 24, 25: ac); albumen duct inserted next to that of albumen chamber (Fig. 24: ad), both forming common short duct inserted in fertilisation complex. Fertilisation complex as simple cylindrical axis between hermaphrodite duct and beginning of spermoviduct (Fig. 24: between hd and eo). Spermoviduct (Figs 23-25: eo) and free oviduct (fo) performing intricate, node-like coils along right side of haemocoel (Fig. 23 as in situ), relatively narrow and long; initial portion of spermoviduct as narrow as adjacent hermaphrodite duct, after short distance subtly expanding, running anteriorly, of equal width along its whole length. Spermoviduct relatively short (ca. 1/4 of entire main region of genital ducts) (Fig. 25), bearing hollow uterus (ut), with undulating, glandular outer walls, ca. $65 \%$ of total size; and prostate (pt), with thick glandular walls, smooth outer surface, internally hollow (Fig. 25: transverse section above "pt"). Vas deferens (Fig. 25: vd) originating on transition to free oviduct, relatively thick. Free oviduct (Fig. 25: fo) with posterior half of similar structure as spermoviduct, except for prostate being solid (transverse section below "pt"); anterior half simpler, wall strongly muscular, mainly in its middle portion, inner surface lacking glandular tissue, forming vaginal tube (vg). Bursa copulatrix small, spherical (Fig. 23: bc), ca. 1/4 of albumen gland's size; located away from genital ducts, close to pericardium (Fig 13: bc); bursa duct relatively thick, running posteriorly to genital ducts, anteriorly parallel to spermoviduct, (Fig. 23: bd); inserting dorsally in female gonopore (Fig. 23: fp). Despite longitudinal furrow connecting female and male gonopores (Fig. 11: gf), vas deferens penetrates adjacent integument, running parallel to the furrow (Figs 23, 25: vd). Close to male gonopore (Fig. 23: ap), vas deferens penetrates integument, exiting to haemocoel, running along penis surface to distal end of penis, penetrating inside penis at base of penial muscle (Figs 23, 25: vd). Penis claviform, broader in apical 2/3, narrow in basal $1 / 3$ (Figs 23, 25: pe). Penis muscle of almost half of penis length and width, inserted apically $(\mathrm{pm})$, originating on right side of columellar muscle (Fig. 15: pm). Penis wall relatively thin in basal half, thick muscular in apical half (Fig. 26). Inner surface of apical half with several papillae, fairly regularly arranged close to basal half, more apically low and wide, becoming gradually narrower and taller toward base, to become finally digitiform (Fig. 26); inner surface of basal half smooth. Penial appendix (Fig. 26: pa) lying bent inside penis chamber; vas deferens running along its 
middle, opening in spoon-like concavity at appendix tip (Fig. 26: va), concavity with papillated edge; appendix of equal width along its length, smooth on one side and with series of transverse folds on the other; each fold with straight edge in basal part, toward tip becoming gradually undulating and more closely spaced. Gonopores described above (headfoot).

Central nervous system (Figs 19-20). Nerve ring located at base of buccal mass (Figs 13-14: nr). Pair of cerebral ganglia (ce) rounded, flattened; cerebral commissure (cc) ca. 1.5 times longer than each ganglion; flattened, relatively wide, ca. half of each ganglion in width. Each cerebral ganglion of ca. 1/4 width of oral tube at corresponding level. Pair of pleural ganglia (pp) separated from remaining ganglia, slightly closer to cerebral ganglia; each one ca. 1/3 size of cerebral ganglion. Pair of pedal ganglia (gp) almost as large as cerebral ganglia, located close to each other, connected by narrow commissure in middle of their ventral surface (Fig. 20). Suboesophageal (su) and visceral (abdominal)-subintestinal ganglion (as) of approximately same size as pleural ganglion; approximately equidistant from both pleural ganglia. Statocysts (sy) with several statoconia, relatively small, connected to dorso-lateral side of pedal ganglia.

Measurements. Holotype: 10.3 by $8.0 \mathrm{~mm}$; MZSP 151286 (Figs 4-7): 10.3 by $8.0 \mathrm{~mm}$.

Distribution. Endemic to the region of Foz do Iguaçu, Paraná, Brazil and Iguazú, Misiones, Argentina (Ovando et al. 2020).

Habitat. Calm-water habitats as well as small and large waterfalls, on muddy bottom and leaf litter.

Material examined. Types. BRAZIL, Paraná, Foz do Iguaçu, Parque Nacional do Iguaçu, fountain close to

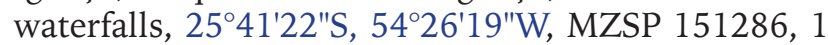
specimen, MZSP 151287 Chilina, 15 specimens.

Remarks. See Discussion.

\section{Order Caenogastropoda}

\section{Family Cochliopidae}

\section{Genus Heleobia Stimpson, 1865}

\section{Heleobia iguassu sp. nov.}

(Figs 27-39)

Types. Holotype MZSP 151282. Paratypes from type locality: MZSP 151283, 10 specimens. urn:1sid:zoobank.org:act:8249B71D-97A9-47A5AC95-329EE97FD7D9

Type locality. BRAZIL, Paraná, Foz do Iguaçu, Parque Nacional do Iguaçu, fountain close to waterfalls, $25^{\circ} 41^{\prime 22} 22^{\prime}$, 5426'19"W [SIMONE col. 04.XII.2019]
Etymology. The specific name refers to the type locality, Iguaçu National Park, which is pronounced as "Iguassu".

Diagnosis. shell relatively small, cylindrical; apex only slightly narrower than body whorl. Protoconch of ca. $270 \mu \mathrm{m}$, brown. Gill and osphradium well-developed. Penis lacking apocrine glands. Pallial oviduct with ingesting gland at end of visceral oviduct, single, long, balloon-like receptacle.

\section{DESCRIPTION}

Shell (Figs 27-31). Shell height ca. $2.5 \mathrm{~mm}$; elongated ovate, ca. twice higher than wide, shallowly umbilicate; whorls convex, suture shallow; adult ca. 5 whorls. Sculpture absent except for growth lines (Figs 27-29, 31). Periostracum thin, colour pale beige, translucent, except for sparsely (Figs 27-29) or densely (Fig. 31) distributed minute spots. Protoconch (Fig. 30) of ca. $270 \mu \mathrm{m}$, with ca. 1.5 smooth whorl; colour brown. Teleoconch of ca. 3.5 whorls. Mean spire angle ca. $35^{\circ}$, apex dome-shaped. Aperture elliptical-oval, ca. $40 \%$ of total shell height, ca. $55 \%$ of shell width, peristome not continuous, attached to penultimate whorl as callus; profile almost orthocline, at ca. $15^{\circ}$ to longitudinal shell axis (Fig. 28); inner lip smoothly concave; outer lip and interior third of inner lip performing continuous semicircle (Figs 27, 31), relatively thin; anal region angled at ca. $55^{\circ}$, with narrow, thin callus; incurrent region widely rounded. Umbilicus very narrow, mostly covered by lower half of peristome inner lip.

Head-foot (Fig. 33). Relatively short, stubby; unpigmented. Mesopodium thick, short, slightly wider than long (fs). Anterior furrow of pedal glands (pg) deep, restricted to anterior edge. Opercular pad elliptic, subterminal, occupying most of posterior dorsal surface of foot. Head (he) bulbous, of ca. $80 \%$ of foot width; pair of cephalic tentacles (te) simple, thick, ca. half as long as foot. Eye (ey) large, on outer side of tentacle base; occupying more than half width of tentacle base. Snout slightly shorter than tentacle; ca. double tentacle width (sn); anterior end rounded, weakly bi-lobed. Columellar muscle thick, ca. 3/4 whorl, gently curving to the right $(\mathrm{cm})$.

Operculum (Figs 27, 31). Corneous, thin, translucent, pale yellow-beige, flexible, paucispiral. Outline semi-circular, ca. 1.3 longer than wide, occupying entire aperture. Nucleus almost subterminal.

Mantle organs (Fig. 32). Pallial cavity ca. 1 whorl in length. Mantle edge simple, hardly thickened, wide; unpigmented. Osphradium (os) short, elliptical, simple; length ca. $10 \%$ of pallial cavity length; 3 times longer than wide; located in anterior-left corner of cavity, close to gill, away from mantle border. Gill (gi) elongated, narrow, ca. $70 \%$ of pallial cavity length 


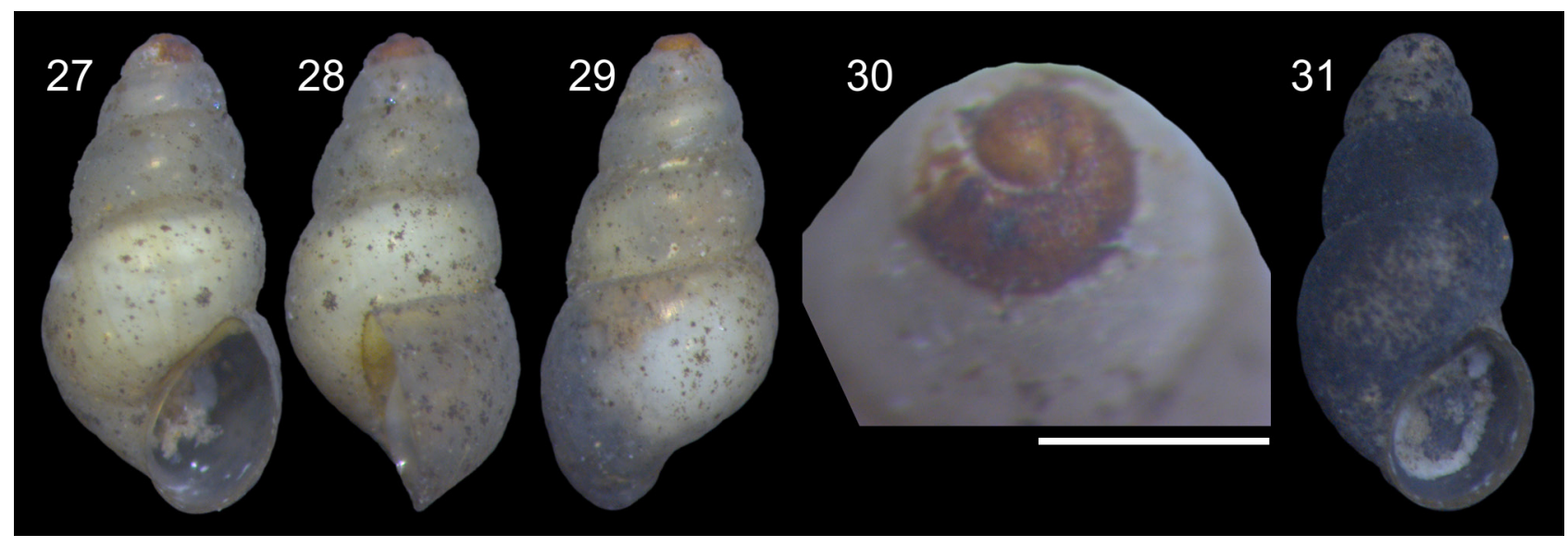

Figs 27-31. Heleobia iguassu sp. nov. shell features: 27-29 - holotype MZSP 151282, frontal, lateral right and dorsal views (shell height $2.35 \mathrm{~mm}$ ), 30 - same, detail of apex, apical view, scale bar $0.25 \mathrm{~mm}, 31$ - paratype 151283, frontal view (shell height $2.37 \mathrm{~mm}$ )

and $1 / 5$ of cavity width; anterior end widely pointed, posterior to mantle edge; width relatively uniform along whole length; lamellae ending at anterior edge of pericardium. Gill lamellae relatively few (ca. 15), approximately isosceles triangular, distal tips blunt (gi). Between gill and rectum narrow gap equivalent to $5 \%$ of pallial cavity width. Hypobranchial gland inconspicuous. Rectum wide, relatively straight, up to $1 / 5$ of pallial cavity width in some points; bearing aligned series of transversely disposed, rounded faecal pellets (Figs 32, 36: fe), easily seen due to translucence; rectum slightly removed from right margin of mantle cavity. Anus simple, short-siphoned, located short distance from mantle border at ca. 5\% of cavity length. Genital ducts running along right-posterior margin, relatively massive (see also below).

Visceral mass (Figs 32, 36). Length ca. 3 whorls. Most structures pale beige to white in colour, mantle unpigmented. Stomach (st) anteriorly located, compressing anteriorly small reno-pericardial structures; ca. 0.5 whorl long, nearly as wide as entire adjacent whorl. Digestive gland light beige, of ca. 2.5 whorls, mostly posterior to stomach. Gonad (oy) running along columellar surface of each whorl in mature specimens. For more details of reproductive and digestive systems see below.

Circulatory and excretory systems (Fig. 32). Pericardium narrow, located longitudinally between stomach and left-posterior corner of pallial cavity (pc), volume ca. 1/20 of that of visceral mass; auricle (au) anterior, small, just posterior to posterior end of ctenidial vein (cv); ventricle (ve) posterior, simple. Kidney (ki) minute, slightly smaller than pericardium, located on right side of posterior end of pallial cavity, mostly hollow; inner tissue loose, white. Nephrostome (ne) small, transverse, located approximately half way between pericardium and adjacent rectum.

Digestive system (Figs 32, 34, 36). Mouth on ventral surface of snout. Buccal mass occupying entire interior of snout and ca. 1/4 of haemocoel volume. Oral tube conical, wide, ca. 1/4 length of buccal mass. Pair of jaw plates (Fig. 34: jw) small, laterally located; each plate ca. 4 times longer than wide, obliquely disposed, very thin, translucent. Pair of buccal ganglia relatively large (bg). Odontophore spherical, ca. half of buccal mass in volume. Odontophore muscular arrangement similar to that in the following species. Radular sac as long as odontophore (Fig. 34: rs); radular nucleus (rn) not widening. Radula (Fig. 39) typical of the genus, rachidian arched, with 5 small, uniform cusps on cutting edge, pair of lateral thickenings, with superior end inflated, cusp-like; lateral tooth with flattened terminal end, with 5 uniform cusps; both marginal teeth similar to lateral tooth, except becoming gradually narrower toward lateral edge.

Salivary gland absent. Oesophagus simple, zigzagging along haemocoel (Fig. 34: es), slightly broader in its mid-region, lacking obvious glandular areas. Stomach dimensions and position described above (visceral mass); main gastric chamber (Figs 32, 36: st) posteriorly located, posterior surface rounded. Style sac narrow (Fig. 32: ss), with ca. half of remaining gastric dimensions. Oesophagus (es) inserting in posterior-left region of stomach; intestinal (in) origin on left side of mid-level of style sac; duct of digestive gland (dd) very narrow, located in middle of posterior-ventral stomach region, running posteriorly. Intestine (in) slightly narrower than oesophagus; anteriorly surrounding style sac up to its right posterior end; in this region faecal pellets appearing, gently curving anteriorly and dorsally running to pallial cavity (for rectum faecal pellets and anus see above - pallial cavity).

Genital system: Male (Figs 35-36). Seminal vesicle (sv) very narrow, feebly convoluted, located in columellar region of visceral mass ventral-posterior to stomach, colour pale grey-iridescent; narrow, straight 
portion of vas deferens, ca. 1/2 whorl in length, inserting subterminally (Fig. 36: sv) at posterior-left part of prostate. Prostate ca. 1/4 of pallial cavity in width, slightly dorso-ventrally flattened, white (Fig. 36: pt). Pallial vas deferens originating in ventral-middle region of prostate, relatively close to visceral insertion of vas deferens (Fig. 36: vd); after short distance pen- etrating floor of pallial cavity up to penis base, running immersed in integument (Fig. 35: vd). Penis (Figs 33, 35: pe), simple, curved, elongated (ca. half of pallial cavity), base fairly broad, gradually tapering to blunt tip. Penis duct seen due to translucence, running straight along middle penial region, up to penis tip (Fig. 35: pd); aperture apical, simple, small.

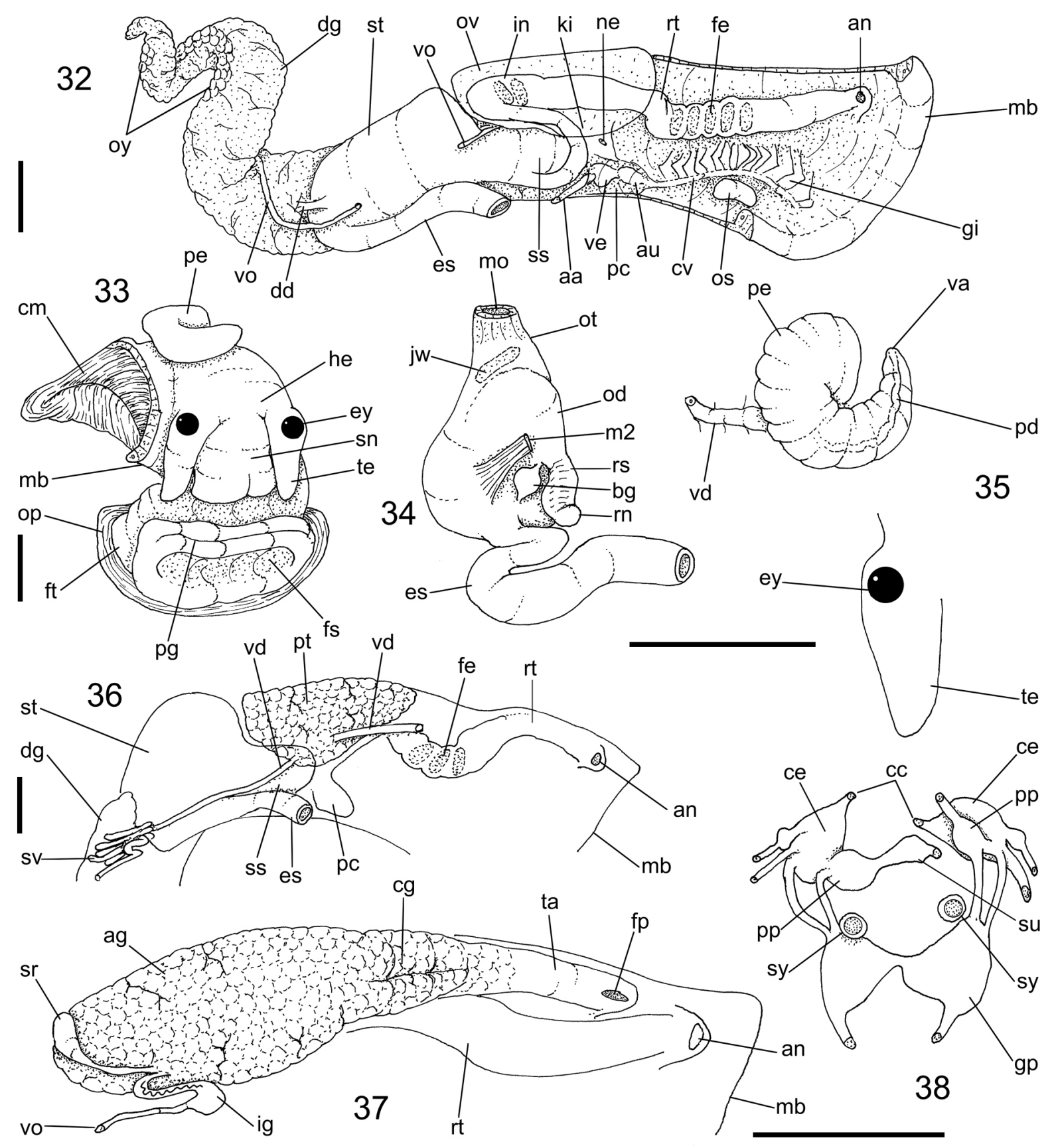

Figs 32-38. Heleobia iguassu sp. nov. anatomy: 32 - pallial cavity roof and partially uncoiled visceral mass, mostly ventral view, oviduct (ov) seen if translucent, 33 - head-foot, male, frontal view, 34 - foregut, left lateral view, jaw (jw) seen due to translucence, 35 - penis and topology of adjacent right tentacle, dorsal view, penis duct (pd) seen due to translucence, 36 - middle male genital structures, ventral view, topology of some adjacent structures also shown, 37 - pallial oviduct and some adjacent structures, ventral view, 38 - central nervous system, ventral view, cerebral commissure (cc) sectioned. Scale bars $0.25 \mathrm{~mm}$. For abbreviations see text p. 14 
Female (Figs 32, 37). Ovary (Fig. 32: oy) described above (visceral mass). Visceral oviduct very narrow, running along middle of columellar surface of visceral mass, for ca. 1 whorl (vo). Visceral oviduct inserting subterminally in posterior-left region of pallial oviduct (Fig. 37: vo). In this region, seminal receptacle protrudes posteriorly and to the right. Ingesting gland (ig) as bulging region at end of visceral oviduct, tapering gradually to its insertion close to origin of seminal receptacle; zigzagging inner tube running along narrow portion of ingesting gland. Seminal receptacle balloon-like, size ca. 1/30 of pallial oviduct (sr). Albumen gland (ag) broad, wide, white, occupying ca. half of pallial oviduct. Capsule gland (cg) white, without clear separation from albumen gland, more differentiated anteriorly, as tapering region with ventral furrow separating both glandular walls. Terminal atrium (ta) of ca. 1/4 of pallial oviduct, cylindrical, walls fairly thin. Female gonopore (fp) short-siphoned, papilla-like, directed anteriorly, located close to and right of anus (an).

Central nervous system (Fig. 38). Nerve ring located just posterior to buccal mass, with pedal ganglia slightly anterior to remaining ganglia. Each cerebral ganglion (ce) oval, of size equivalent to oesophageal section; cerebral commissure (cc) narrow, ca. half length of each ganglion. Pair of tentacular nerves, each with bulging, ganglion-like portion at their origin in cerebral ganglia. Pleural ganglia (pp) ca. 1/3 size of cerebral ganglia, located just ventral to them, separated from cerebral ganglia by constriction. Each pedal ganglion (gp) slightly larger than cerebral ganglion, somewhat spherical, pedal commissure narrow, ca. 1/4 ganglion length. Cerebro-pedal and pleuro-pedal connectives approximately as long as pedal ganglia. Suboesophageal ganglion (su) almost as large as pleural ganglion, located short distance from right pleural ganglion. Pair of statocysts (sy) located on ventro-anterior side of pedal ganglia; left statocyst slightly farther from ganglion than right statocyst.

Measurements. Holotype 2.35 by $1.19 \mathrm{~mm}$.

Distribution. Known from the type locality only.

Habitat. Found under leaves on the bottom of the fountain.

Material examined. Types.

Remarks. See Discussion.

\section{Family Tateidae}

Genus Potamolithus Pilsbry, 1896

Potamolithus mirim sp. nov.

(Figs 40-58)

Types. Holotype MZSP 151284. Paratypes from type locality: MZSP 151285, 15 specimens.
urn:1sid:zoobank.org:act:C3D0249D-A9F1-4462BE4F-D052F8A2BB28

Type locality. BRAZIL, Paraná, Foz do Iguaçu, Parque Nacional do Iguaçu, fountain close to waterfalls, $25^{\circ} 41^{\prime} 22^{\prime \prime}$ S, 54 26'19"W [SIMONE col. 04.XII.2019].

Etymology. The specific epithet is derived from the native language Tupi-Guarani, mirim, meaning small, minute, alluding to the small size of the species compared to its congeners.

Diagnosis. Shell small, almost as high as wide, relatively thin-walled; umbilicus opened; subsutural shoulder lacking. Intestine originating at mid-level of style sac. Odontophore with anteriorly situated insertion of pair m5. Penis with apical papilla in lateral position. Pallial oviduct with bursa and receptacle long and located close to each other.

\section{DESCRIPTION}

Shell (Figs 41-45, 48-51). Size ca. $3.0 \mathrm{~mm}$; globose-conical, approximately as high as wide, narrowly umbilicate; whorls convex, suture relatively deep; weak, obsolete subsutural shoulder; adult ca. 4 whorls. Sculpture absent except for growth lines (Figs 42, 43, 49), sometimes regularly undulating close to suture (Fig. 44). Colour greenish pale brown, slightly translucent (Fig. 49-51), periostracum thin, simple. Protoconch (Fig. 45) ca. $290 \mu \mathrm{m}$, with ca. 1.0 smooth whorl; colour brown. Teleoconch of ca. 3 whorls. Mean spire angle ca. $110^{\circ}$, apex blunt. Aperture rounded, peristome not continuous, attached to penultimate whorl as callus; ca. $65 \%$ of total shell height, ca. $60 \%$ of shell width; profile prosocline, at ca. $35^{\circ}$ to longitudinal shell axis (Figs 43, $48,50)$; inner lip smoothly concave, simple; outer lip as semi-circle (Figs 41, 48, 50), relatively thin; anal region angled at ca. $100^{\circ}$, with narrow, thin callus; incurrent region widely rounded. Umbilicus narrow, mostly covered by lower $2 / 3$ of peristome inner lip on the right side, and by weak carina on the left side (Figs 41, 43, 48, 50).

Operculum (Figs 46-47). Corneous, thin, translucent, pale brown, flexible, paucispiral. Outline elliptical, ca. 1.3 longer than wide. Nucleus in middle of inner-lower quarter. Slightly smaller than aperture (Figs 48, 50).

Head-foot (Fig. 53). As in the preceding species, with the following differences: foot unpigmented, snout and tentacles base with dark brown wide spots. Pair of cephalic tentacles (te) with eye region distinctly broader than more apical regions. Snout slightly dorso-ventrally flattened; anterior end bilobed. Columellar muscle $(\mathrm{cm})$ thick, ca. 3/4 whorl. Mantle organs (Figs 52, 57). General characters as in the preceding species, with the following characteristic features. Pallial cavity ca. $3 / 4$ whorl in length. 
Osphradium (os) long, ridge-like, simple; length ca. $20 \%$ of pallial cavity length; 5 times longer than wide; located in anterior-left corner of cavity, close to and at mid-level of gill, away from and parallel to mantle border. Gill (gi), ca. $90 \%$ of pallial cavity in length and $1 / 5$ of cavity width; anterior end pointed, touching mantle edge. Gill lamellae rather tall, triangular, ca. 1.5 taller than wide. Rectum wide, forming wide curve (concavity right); bearing aligned, rounded faecal pellets (fe), easily seen due to translucence. Visceral mass (Fig. 52). As in the preceding species, except for length of ca. 2 whorls; and for mantle locally pigmented by dark brown, wide, coalescent spots.

Circulatory and excretory systems (Fig. 52). As in the preceding species.

Digestive system (Figs 52, 54, 55). Most characters similar to those of the preceding species, with the
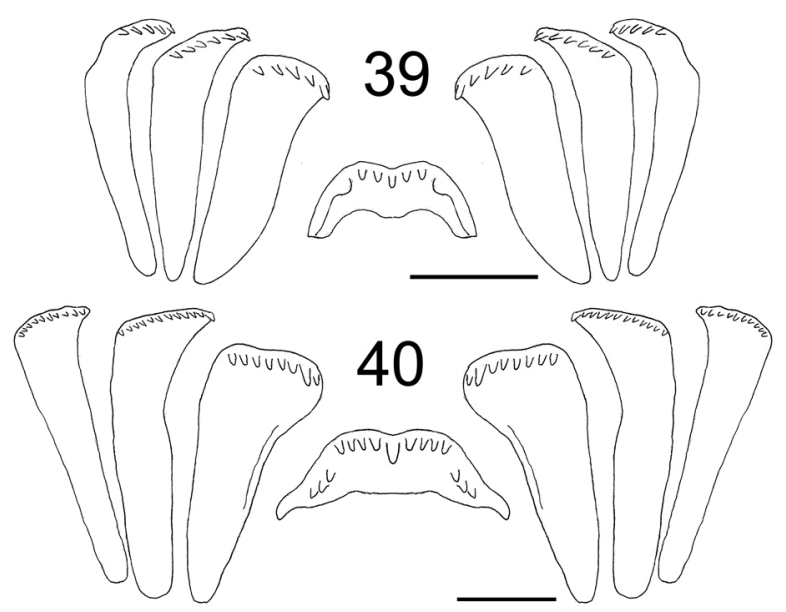

Figs 39-40. Radulae: 39 - Heleobia iguassu sp. nov., 40 Potamolithus mirim sp. nov. Scale bars $0.1 \mathrm{~mm}$

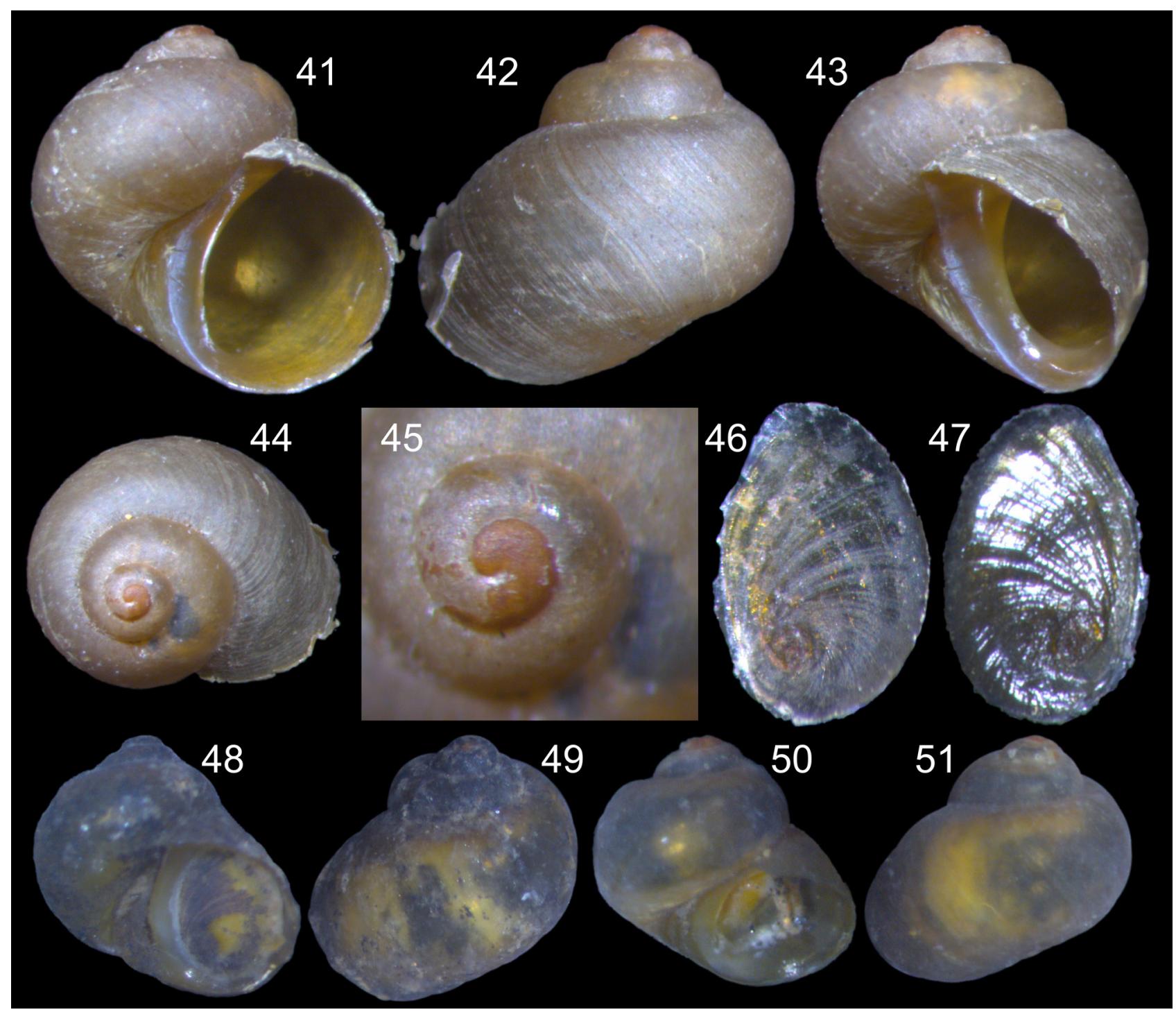

Figs 41-51. Potamolithus mirim sp. nov. shell and operculum: 41-44 - holotype MZSP 151284 female shell (shell width 2.59 $\mathrm{mm}$ ), frontal, dorsal right and apical views, 45 - holotype, detail of apex, apical view (base $=1 \mathrm{~mm}$ ), 46 - operculum of holotype, external view (width $1.35 \mathrm{~mm}$ ), 47 - same, internal view, $48-51$ - paratypes 151285 , frontal and dorsal views, 48-49 - male 3 (shell width $2.53 \mathrm{~mm}$ ), 50-51 - male 4 (shell width $2.15 \mathrm{~mm}$ ) 
following differences. Pair of buccal ganglia relatively small (bg). Odontophore muscular arrangement (Figs 54-55): $\mathbf{m} 2$ - pair of posterior retractor muscles of odontophore, narrow, originating in latero-ventral region of haemocoel inner surface, at its mid-level, running anteriorly and dorsally for distance slightly shorter than buccal mass length, inserting in postero-lateral region of odontophore, to its cartilages;

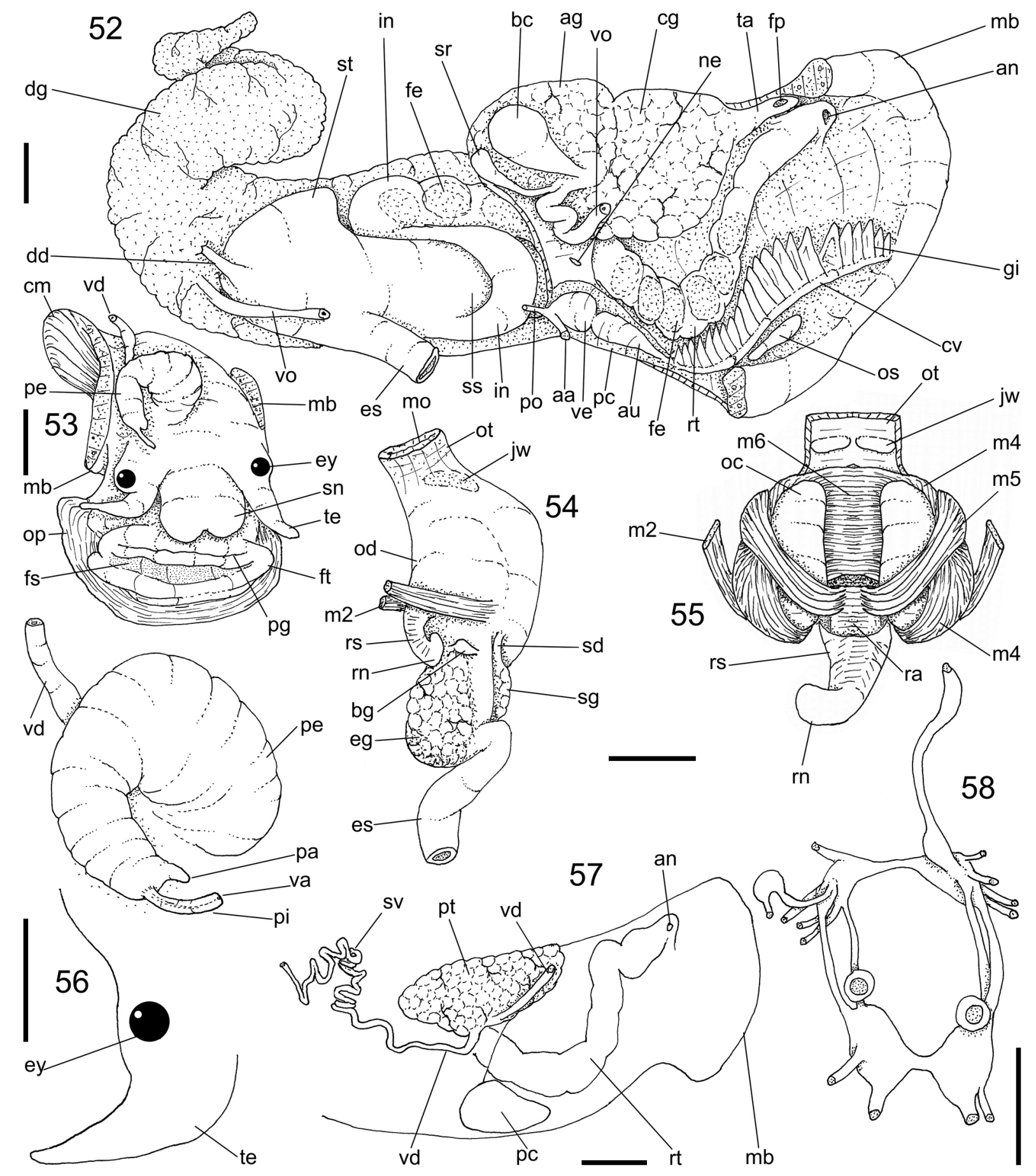

Figs 52-58. Potamolithus mirim sp. nov. anatomy: 52 - pallial cavity roof and partially uncoiled visceral mass, female, mostly ventral view, 53 - head-foot, male, frontal view, 54 - foregut, left lateral view, 55 - odontophore, dorsal view, superficial layer of structures removed, both cartilages (oc) deflected, 56 - penis and topology of adjacent right tentacle, dorsal view, 57 - middle male genital structures, ventral view, topology of some pallial structures shown, 58 - central nervous system, ventral view. Scale bars $0.25 \mathrm{~mm}$. For abbreviations see text p. 14 
$\mathrm{m} 4$ - pair of main dorsal tensor muscles of radula, broad and thick, surrounding outer lateral surface of odontophore cartilages (oc), originating from their ventro-lateral surface, inserting on lateral edges of subradular cartilage in region in buccal cavity, and also in radular sac region preceding buccal cavity; m5 - pair of secondary dorsal tensor muscles of radula, narrow and thin, originating in antero-lateral surface of $\mathrm{m} 4$, running medially and posteriorly, between cartilages, inserting on ventral side of radular ribbon in its region exposed in buccal cavity (Fig. 55); $\mathrm{m} 6$ - horizontal muscle, thin and wide, connecting ventral edge of both odontophore cartilages along ca. $75 \%$ of their length (Fig. 55). Odontophore cartilages elliptic, somewhat flattened laterally, ca. 2.5 longer than wide, anterior and posterior edges rounded and similar (Fig. 55: oc).

Radular sac ca. 1.5 times longer than odontophore (Fig. 54: rs); radular nucleus (rn) not widening. Radula (Fig. 40) typical of the genus; rachidian arched, with 9 cusps in cutting edge, central cusp almost twice larger than others, 3 pairs of basal-lateral cusps; lateral tooth with wide, blunt terminal region, with 8-9 small cusps, subterminal cusp slightly larger; marginal teeth similar to lateral tooth, except for being less arched and becoming gradually narrower towards lateral edge, with 10-12 very small cusps.

Salivary gland small, covering origin of oesophagus; pair of salivary ducts discernible, running for short distance before penetrating latero-dorsal region of buccal cavity posterior end (Fig. 54: sd). Oesophagus zigzagging along haemocoel (Fig. 54: es), distinctly broader in its anterior region due to ventral oesophageal gland (Fig. 54: eg). Style sac relatively broad (Fig. 52: ss), ca. 1.5 times longer than main gastric chamber. Oesophagus (es) inserting in middle level of gastric left region; intestinal (in) origin on left side of middle level of style sac. Intestine (in) as broad as oesophagus; its course as in the preceding species, except running ventrally, at middle level of style sac, and making stronger curve in pallial cavity. Rectum faecal pellets and anus described above (pallial cavity).

Genital system: Male (Figs 53, 56-57). General structure as in the preceding species. Characteristic features as follows. Seminal vesicle (sv) very narrow, convolutions slightly more spread in ventralposterior direction to stomach. Insertion of visceral vas deferens and origin of pallial vas deferens close to each other, in ventral-middle region of prostate (Fig. 57: vd). Penis (Figs 53, 56: pe) with sharply pointed, asymmetrical tip (pa); with long papilla on opposite side of tip (pi) (ca. 3 times longer than pointed tip). Penis duct opening on tip of papilla (va).

Female (Figs 52). Most features as in the preceding species, with the following differences. Visceral oviduct relatively broad (vo), inserting in left-anterior corner of albumen gland (ag). Seminal receptacle (sr) narrow, almost as long as albumen gland width, distal end fairly broad. Bursa copulatrix (bc) similar to seminal receptacle in length, but ca. 4 times broader, inserted just anterior to insertion of seminal receptacle. Albumen gland (ag) occupying almost half of pallial oviduct. Capsule gland (cg) ca. 1.5 times larger than albumen gland. Terminal atrium (ta) ca. 1/5 of pallial oviduct, cylindrical, walls poorly thickened. Female gonopore (fp) short-siphoned.

Central nervous system (Fig. 58). Ganglia and connectives slightly more elongated than those of the preceding species. Commissures of same size as in the preceding species.

Measurements. Holotype 2.44 by $2.59 \mathrm{~mm}$.

Distribution. Known from the type locality only.

Habitat. Found under leaves on the bottom of the fountain.

Material examined. Types.

Remarks. See Discussion.

\section{DISCUSSION}

Though Scott was an excellent anatomist, he provided no anatomical information in his original description of Chilina megastoma (SCOTT 1958). Later, only ITUARTE (1997) presented relevant anatomical information, with more detail on the radula and the nerve ring. In order to put the present anatomical investigation in taxonomic and phylogenetic context, the comparison extends to cover congeneric species, and the hygrophilans as a whole.

The head structure of Chilina (Figs 11, 13, 15, 23; HAECKEL 1911: figs 10-11; BRACE 1983: fig. 1) is more similar to that of the marine Siphonaria (MARCUS \& MARCUS 1962, SimONE \& SEABRA 2017) than to the other hygrophilans, which have more de-

veloped tentacles and eyes at the base of tentacles occupying a more central position. However, the siphonariids lack tentacles altogether, while Chilina has small flap-like tentacles. The foot of Chilina looks bipartite, with a bi-lobed anterior region resembling a wide snout, and an ample mesopodial sole (Fig. 11; BRACE 1983: fig. 1b). The mouth (mo) is situated in the middle of the snout-like projection, at its boundary with the mesopodial sole, ventrally instead of anteriorly (Fig. 15: mo). This is another feature shared with Siphonaria, which, in contrast, has the mouth in a slightly more anterior position, away from the anterior edge of the mesopodium. 
The head-foot musculature of C. megastoma is rather typical of a coiled gastropod, with the columellar muscle of ca. 1.5 whorl. The pair of ventral retractors (Fig. 15: hm) is somewhat different, possibly developed to help the contraction of anterior edge of the wide flap-like head. Moreover, the insertion of the radular muscle (Fig. 15: $\mathrm{m} 2$ ) and the ventral insertion of penis muscle ( $\mathrm{pm})$, along the columellar muscle, is usual in pulmonates; the only difference is the lateral insertion of the penis muscle (pm), which in other species is usually more central.

The pallial cavity of C. megastoma is similar to those of the remaining chilinids. However, there is no ventral ciliary band; it is found in C. fluctuosa (BRACE 1983: fig. 3b). The pneumostome of the chilinids (Fig. 10: pn) lacks sphincter and capacity of closure. This is a normal condition for the hygrophilans as aquatic forms, as opposed to the stylommatophorans; however, as possible exception, there are grooves for conducting faecal and urinary matter respectively in the right and left regions of the pneumostome (Fig. 10: af, uf). The Chilina kidney and pericardium are flattened and amply exposed inside the pallial cavity (Fig. 10). The renal vessel runs along the central region of the kidney (BRACE 1983, as collecting sinus), an arrangement different from that found in the planorbids, lymnaeids and physids (PARAENSE \& DESLANDES 1955a, PARAENSE $1982,1984,1995,2003)$ in that the kidney is very much elongated and the renal vessel lies on the opposite side of the pulmonary vein. The pulmonary vein (Fig. 10: cv), which is homologous to the ctenidial vein of gill-bearing taxa, lies along the anterior and left margins of the kidney, extending up to its connection with the auricle (Fig. 10: au). The ureter, which in other hygrophilans is relatively long, is very short in Chilina, which has the nephropore (Fig. 10: ne) preceded only by a very small tube. The respiratory system of Chilina lacks a distinct secondary gill, which in the siphonariids extends along the cavity (SIMONE \& SEABRA 2017), and in the other hygrophilans is usually located close to or on the mantle border (PARAENSE 1987, 2002, SIMONE et al. 2012). On the other hand, the arrangement of kidney and pulmonary vein of the chilinids resembles the ordinary organisation of the gill-bearing aquatic taxa. The kidney is located in the same position as the gill, draining blood directly via the main vein to the auricle. As the auricle usually receives oxygenated blood, the kidney may serve to promote ventilation. Its interior contains transverse septa (Fig. 10: ki), arranged in the same way as gill filaments. No distinct pulmonary vessels are visible. C. megastoma, on the other hand, has well-developed longitudinal blood sinuses in the right side (Fig. 10: ar); they certainly contribute to blood oxygenation, despite apparently not draining to the heart.
In the digestive system, the odontophore arrangement is typical of advanced tectipleurans, with a pair of well-developed, relatively rigid odontophore cartilages (Figs 17-18: oc). Both cartilages are extensively fused with each other along the median line, retaining only small concavities on both ends. No horizontal muscle (m6) was detected in C. megastoma, however, the muscle was reported, as "intracartilage tensor muscles" in C. fluctuosa (BRACE 1983: fig. 9b). The weakly developed or absent $\mathrm{m} 6$ is usual in pulmonates, which usually have widely fused cartilages (e.g., SimONE et al. 2012, SIMONE \& SEABRA 2017). The pair of main dorsal tensor muscles of the radula is very thick in Chilina (Figs 17-18: m4) (BRACE 1983, as supralateral radular retractor muscle). On the other hand, the auxiliary dorsal tensors (m5) (supramedian radular retractor muscle by BRACE 1983) are narrow and fairly thin, and untypically, insert on the postero-dorsal surface of the cartilages; usually they insert on the posterior edge of cartilages or on $\mathrm{m} 4$. The insertion of jaw muscles (mj) of C. megastoma is close to the median line, and relatively posteriorly; usually their insertions are in a more anterior and lateral position. The pair of odontophore retractors (Figs 14, 16, 18: m2) (dorsolateral levator muscle in BRACE 1983), are relatively anteriorly inserted; the retractors have two insertions each: one splayed along $\mathrm{mj}$, and another more internal, on the cartilages (Fig. 18: m2).

In the midgut, the Chilina stomach is very unusual. It is preceded by a huge oesophageal, muscular gizzard (Fig. 13: gz), which so far has only been reported by HARRY (1964: fig. 9), as "muscular stomach". Its internal structure is described here for the first time, and consists of a pair of opposed muscular pistons (Figs 21, 22: gm), externally connected with each other by a muscular belt $(\mathrm{mc})$. Both pistons have a flat surface of contact, suggesting a strange way of smashing the food. The stomach itself, marked by the duct of the digestive gland, is relatively simple and narrow, consisting only of a T-shaped region (Figs 13, 21: st); the oesophageal outlet (es), the intestinal inlet (in) and the digestive gland duct (dd) have the form of three tubes of approximately equal size. A small caecum (dv) is present at the intestinal inlet (HARRY 1964, as gastric caecum). It is almost entirely filled by a pair of glandular folds (Fig. 21: dv).

With respect to the genital system, C. megastoma differs from $C$. iguazuensis Gutiérrez Gregoric et Rumi, 2008 (GUTIÉRREZ GREGORIC \& RUMI 2008: fig. 5) in lacking secondary bursa, in having a much longer prostate, and in a more uniform width of the spermoviduct along its length. It differs from C. nicolasi Gutiérrez Gregoric et de Lucía, 2016 (GUTIÉRREZ GREGORIC \& DE LUCÍA 2016: fig. 3A) in the lack of external division of the penis into praeputium and penis sheath; and from C. dombeiana (Bruguiére, 1789) (HAECKEL 1911: fig. 29) in a much more elon- 
gated spermoviduct, a less complex carrefour region (Fig. 24), and in the lack of connection of the bursa to the base of the penis. It differs from C. fluctuosa (Gray, 1828) (HARRY 1964: fig. 14) in having a smaller bursa copulatrix, and in the lack of either separate seminal vesicle or vaginal seminal vesicle. The penis of Chilina appears to be very peculiar: at least in those species for which the internal penis structure is known in detail (HARRY 1964: fig. 19, GUTIÉRREZ GREGORIC \& DE LUCÍA 2016: fig. 3B), the penis has an internal appendix or projection (Fig. 26: pa). This appendix is called "penis" by the previous authors, with the remaining portions referred to as praeputium and sheath. However, the entire copulatory organ is homologous to the ordinary penis or phallus of the remaining pulmonates. Thus, what the previous authors called praeputium, penis sheath and penis, actually combine to form the entire penis, as those parts are everted during copulation.

A separate penis, situated anterior to the remaining genital organs, which opens more posteriorly (Fig 11: ap, fp respectively), is the normal pattern in the hygrophilans, as well as in several opisthobranchs (e.g., nudibranchs and aplysiomorphs), suggesting a plesiomorphic condition. The genital system components, however, are usually similar in all the hygrophilan groups. Details of the interrelations among these components and their internal structures are, nevertheless, difficult to analyse, and are only rarely discussed in literature. The chilinids differ from the planorbids (e.g., PARAENSE \& DESLANDES 1955a, b, PARAENSE 1981, 1988, 1996, 2002, 2003, SIDEMAN et al. 1985, IBIKOUNLÉ et al. 2008, SiMONE et al. 2012) in the lack of seminal vesicle located along the hermaphrodite duct, and of digitiform prostate, in having a much elongated bursa copulatrix, and the single penial muscle. They differ from the lymnaeids (e.g., PARAENSE 1982, 1984, 1995, 2003, CAMPBELL et al. 2017) in having much more elongated genital ducts, in lacking seminal vesicle along the hermaphrodite duct, in lacking nidamental gland, and in the prostate located along the spermoviduct. In contrast to the physids (e.g., PARAENSE 1986, 1987, 2003, PARAENSE \& PONTIER 2003, TAYLOR 2003), the chilinids lack seminal vesicles along the hermaphrodite duct, or digitiform prostate, and they have a less complex posterior region of the penis.

The chilinid central nervous system appears to be less concentrated than those of the other hygrophilan groups (e.g., VAZ 1979, PARAENSE 1986: fig. 23). The nerve ring of C. megastoma (Fig. 19) is similar to those of C. fluctuosa (HARRY 1964: fig 13, BRACE 1983: fig. 7), and C. bombeana (HAECKEL 1911: figs. $38,40)$, differing only in the narrower pedal commissure (Fig. 20). C. megastoma differs from C. iguazuensis (GUTIÉRREZ GREGORIC \& RUMI 2008: fig. 6), C. nicolasi Gutiérrez Gregoric et de Lucía, 2016, C. santia- goi Gutiérrez Gregoric et de Lucía, 2016 and C. luciae Gutiérrez Gregoric et de Lucía, 2016 (GUTIÉRREZ GREGORIC \& DE LUCÍA 2016: figs. 3C, 6C, 7C resp.) in having a less symmetrical nerve ring and a thicker cerebral commissure.

The elongation of the shell with uniform growth, and the absence of surface sculpture place one of the new species (H. iguassu) in the genus Heleobia. It differs from most of its congeners reported from Brazil (SIMONE 2006a, as Littoridina) in the fairly cylindrical shell, i.e., the apex only slightly narrower than the body whorl, and in the dark brown protoconch (Fig. 30). The comparisons below focus on the species which also have cylindrical shells: $H$. inconspicua (Haas, 1838) from N. E. Brazil, and H. nana (Marcus et Marcus, 1963). H. iguassu differs from these species in having a more elongated shell, a broader apex and a deeper suture. The minute size of $H$. iguassu is also quite exceptional; Heleobia usually reaches 4-6 $\mathrm{mm}$. Only H. inconspicua, H. nana and H. pusilla (Haas, 1949) are comparable in size with $H$. iguassu. The new species differs from $H$. pusilla in having a more cylindrical shell, a wider protoconch and a narrower peristome.

The anatomical structure of $H$. iguassu is typical of the rissooideans/truncatelloideans (DA SILVA 2003, SIMONE 2006b, 2011), including a proportionally huge stomach (Fig. 32) and pallial genital structures (Figs 32, 36, 37). Despite its minute size, the species has a gill and a large osphradium (Fig. 32). The penis lacks apocrine glands, which are found in most species on both sides or in the external edge of the penis (e.g., DA SILVA 2003, DA SILVA \& VEITENHEIMER-MENDES 2004: fig 19, COLLADO 2015). The arrangement of the pallial oviduct (Fig. 37) is unusual, with an ingesting gland at the end of the visceral oviduct, and a very long, balloon-like receptacle, both connected to the albumen gland close to each other.

Potamolithus mirim has an almost globular shell, with strongly prosocline peristome, which indicates the affiliation with the South American genera (DA SILVA 2003, SIMONE 2006a). P. mirim is very small (up to $3 \mathrm{~mm}$ ) compared to its congeners, which usually exceed $5 \mathrm{~mm}$. Its opened umbilicus (Figs 41, 43, 48, 50 ) is shared with a few of its congeners, and the following comparisons focus on those species. P. mirim differs from P. catharinae Pilsbry, 1911 in a wider shell, with the spire lower and with a greater angle, and in the thinner peristome. In contrast to $P$. philippianus Pilsbry, 1911 it lacks a well-developed subsutural shoulder, has a thinner shell, and a wide peri-umbilical keel. It differs from P. chloris Pilsbry, 1911 and from P. fodinarum Pilsbry, 1924 in having a much wider shell, with thinner walls, and a wider umbilicus. The minute size of $P$. mirim is comparable to $P$. karsticus Simone et Moracchioli, 1994 and P. troglobius Simone et Moracchioli, 1994; it differs from both in having a much wider shell and an opened umbilicus. 
P. mirim displays the usual anatomical features of the genus (DAVIS \& DA SILVA 1984, SIMONE \& MORACCHIOLI 1994, DA SILVA 2003). The origin of the intestine at the mid-level of the style sac (Fig. 52 ) is so far unique; in the remaining known species the intestine departs at the style sac's base. The odontophore muscles (Fig. 55) are here described for the first time in the genus; their main characteristic feature is the anterior insertion of the pair $\mathrm{m} 5$, which normally inserts in the posterior region of the odontophore. At the present state of knowledge, it is impossible to decide if the character is diagnostic at any taxonomic level, and which level it is. The penis of P. mirim has an apical papilla (Fig. 56), which it shares with $P$. aff. ribeirensis (sensu DAVIS \& DA SILVA 1984) and P. ribeirensis (Pilsbry, 1911) (SIMONE \& MORACCHIOLI 1994: fig. 11A), but P. mirim differs in the lateral position of the papilla, and in the lack of penial gland at the papilla's base. In P. mirim the bursa copulatrix and seminal receptacle (Fig. 52) are inserted side by side, close to each other in the posterior region of pallial oviduct; the differences are the length of both structures, much longer than in the other known species.

\section{REFERENCES}

BichuetTe M. E., TRAJANO E. 2018. Diversity of Potamolithus (Littorinimorpha, Truncatelloidea) in a high-diversity spot for troglobites in southeastern Brazil: role of habitat fragmentation in the origin of subterranean fauna, and conservation status. Subterranean Biology 25: 61-88. https://doi.org/10.3897/subtbiol.25.23778

BOUCHET P., RocROI J. P. 2005. Classification and nomenclator of gastropod families. Malacologia 47: 1-397.

BRACE E. C. 1983. Observations on the morphology and behaviour of Chilina fluctuosa Gray (Chilinidae), with a discussion on the early evolution of pulmonate gastropods. Philosophical Transactions of the Royal Society of London B 300: 463-491.

https://doi.org/10.1098/rstb.1983.0017

BRITO M. C. W. 2014. Guia de fauna do Parque Nacional do Iguaçu. WWF, Iguaçu.

Campbell D. C., Clark S. A., Lydeard C. 2017. Phylogenetic analysis of the Lancinae (Gastropoda, Lymnaeidae) with a description of the U. S. federally endangered Banbury Springs lanx. ZooKeys 663: 107-132. https://doi.org/10.3897/zookeys.663.11320

COLlado G. A. 2015. A new freshwater snail (Caenogastropoda: Cochliopidae) from the Atacama Desert, northern Chile. Zootaxa 3925: 445-449. https://doi.org/10.11646/zootaxa.3925.3.9

Cuezzo M. G., Gutiérrez Gregoric D. E., Pointier J. P., VÁzQUez A. A., ITUARTE C., MANSUR M. C. D., ARRUdA J. O., BARKer G. M., SANTOS S. B., Ovando X. M. C., Lacerda L. E. M., Fernandez M. A., Thiengo S. C., Mattos A. C., Silva E. F., Berning M. I., Collado
The current division of the penis-bearing basal caenogastropods into three superfamilies Rissooidea, Truncatelloidea and Littorinoidea - has been contested in morphological analyses (e.g., SIMONE 2006b, 2011). The argument includes a set of synapomorphies, indicating a monophyletic origin of these three taxa. Jointly, they can be considered as Rissooidea, but even if they maintain the superfamily rank, they should be combined into a single monophyletic taxon, possibly a suborder.

The three species described herein, two of them being new, found in a very popular tourist place, show how little is known about the Brazilian limnic malacofauna. At present, the three species seem to be endemic to the Iguaçu region. This indicates that measures should be taken to protect them. Chilina megastoma was only known to occur in the Argentinian part of the Iguaçu region; the present record is the first one from the Brazilian territory.

\section{ACKNOWLEDGEMENTS}

I thank GUSTAVO DARRIGRAN, MLP, for permission to photograph the types of Chilina megastoma.

G. A., Miyahira I. C., Antoniazzi T. N., Pimpão D. M., DAmboreneA C. 2020. Phylum Mollusca. In: DAMboreneA C., Rogers D. C., ThORP J. H. (eds). Thorp and Covich's freshwater invertebrates. Keys to Neotropical and Antarctic fauna. Academic Press, Cambridge, MA, pp. 261-430.

DAVIS G. M., SILVA M. C. P. DA 1984. Potamolithus: morphology, convergence, and relationships among hydrobioid snails. Malacologia 25: 73-108.

DUNCAN C. J. 1960. The genital systems of the freshwater Basommatophora. Proceedings of the Zoological Society of London 135: 339-355.

https://doi.org/10.1111/j.1469-7998.1960.tb05851.x

GuTIÉRREZ GREGORIC D. E., LUCÍA M. DE 2016. Freshwater gastropods diversity hotspots: three new species from the Uruguay River (South America). PeerJ 4: e2138. https://doi.org/10.7717/peerj.2138

Gutiérrez Gregoric D. E., NúÑes V., Rumi A. 2010. Population studies of an endemic gastropod from waterfall environments. American Malacological Bulletin 28: $159-165$.

https://doi.org/10.4003/006.028.0210

GutiérRez Gregoric D. E., NúÑES V., RuMi A. 2012. Population dynamics of freshwater gastropod Chilina fluminea (Chilinidae) in a temperate climate environment in Argentina. Veliger 51: 109-116.

GUTIÉRREZ GREGORIC D. E., RUMI A. 2008. Chilina iguazuensis (Gastropoda: Chilinidae), new species from Iguazú National Park, Argentina. Malacologia 50: 321-330. https://doi.org/10.4002/0076-2997-50.1-2.321 
HAECKEL W. 1911. Beitrage zur Anatomie der Gattung Chilina. Zoologische Jahrbücher, supplement 13: 89136, pls 7-11.

HARRY W. H. 1964. The anatomy of Chilina fluctuosa Gray reexamined, with prolegomena on the phylogeny of the higher limnic Basommatophora (Gastropoda: Pulmonata). Malacologia 1: 355-385.

HERSHLER R., THOMPSON F. G. 1992. A review of the aquatic gastropod subfamily Cochliopinae (Prosobrancha: Hydrobiidae). Malacological Review, supplement 5: $1-140$.

Ibikounlé M., MAssougbodji A., SAKiti N. G., Pointier J. P., MONÉ H. 2008. Anatomical characters for easy identification between Biomphalaria pfeifferi, Helisoma duryi and Indoplanorbis exustus during field surveys. Journal of Cell and Animal Biology 2: 112-117.

ITUARTE C. F. 1997. Chilina megastoma Hylton Scott, 1958 (Pulmonata: Basommatophora): a study on topotypic specimens. American Malacological Bulletin 14: 9-15.

KABAT A. R., HERSHLER R. 1993. The prosobranch snail family Hydrobiidae (Gastropoda: Rissooidea): review of classification and supraspecific taxa. Smithsonian Contributions to Zoology 547: 1-94.

Koch E., MarTin S. M., CiOCCO N. F. 2015. A molecular contribution to the controversial taxonomical status of some freshwater snails (Caenogastropoda: Rissooidea, Cochliopidae) from the Central Andes desert to Patagonia. Iheringia, Série Zoologia 105: 69-75. https://doi.org/10.1590/1678-4766201510516975

MARCUS E., MARCUS E. 1962. On Siphoraria hispida. Botelim da Faculdade de Filosofia, Ciências e Letras da Universidade de São Paulo, Zoologia 24: 107-140.

Ovando X. M. C., GutiérReZ Gregoric D. E. 2012. Systematic revision of Chilina Gray (Gastropoda: Pulmonata) from northwestern Argentina and description of a new species. Malacologia 55: 117-134. https://doi.org/10.4002/040.055.0108

OvANDO X. M. C., LACERDA L. E. M., SANTOS S. B. 2020. Is Chilina megastoma, an endemic and restricted distribution freshwater snail, endangered even trough protected? Tentacle 28: 21-23.

PARAENSE W. L. 1981. Biomphalaria occidentalis sp. n. from South America (Mollusca Basommatophora Pulmonata). Memórias do Instituto Oswaldo Cruz 76: 199-211. https://doi.org/10.1590/S0074-02761981000200011

PARAENSE W. L. 1982. Lymnaea rupestris sp. n. from southern Brazil (Pulmonata: Lymnaeidae). Memórias do Instituto Oswaldo Cruz 77: 437-443. https://doi.org/10.1590/S0074-02761982000400011

PARAENSE W. L. 1984. Lymnaea diaphana: a study of topotypic specimens (Pulmonata: Lymnaeidae). Memórias do Instituto Oswaldo Cruz 79: 75-81. https://doi.org/10.1590/S0074-02761984000100009

PARAENSE W. L. 1986. Physa marmorata Guilding, 1828 (Pulmonata: Physidae). Memórias do Instituto Oswaldo Cruz 81: 459-469.

https://doi.org/10.1590/S0074-02761986000400014
PARAense W. L. 1987. Physa cubensis Pfeiffer, 1839 (Pulmonata: Physidae). Memórias do Instituto Oswaldo Cruz 82: 15-20. https://doi.org/10.1590/S0074-02761987000100003

PARAENSE W. L. 1988. Biomphalaria kuhniana (Clessin, 1883), planorbid mollusc from Douth America. Memórias do Instituto Oswaldo Cruz 83: 1-12. https://doi.org/10.1590/S0074-02761988000100001

PARAENSE W. L. 1995. Lymnaea cousini Jousseaune, 1887, from Ecuador (Pulmonata: Lymnaeidae). Memórias do Instituto Oswaldo Cruz 90: 605-609. https://doi.org/10.1590/S0074-02761995000500011

PARAENSE W. L. 1996. Neotropical planorbid snails with apertural lamellae. I. Biomphalaria helophila (Orbigny, 1835). Memórias do Instituto Oswaldo Cruz 91: 177186.

https://doi.org/10.1590/S0074-02761996000200010

Paraense W. L. 2002. Plesiophysa dolichomastix sp. n. (Gastropoda: Planorbidae). Memórias do Instituto Oswaldo Cruz 97: 505-508. https://doi.org/10.1590/S0074-02762002000400009

PARAENSE W. L. 2003. Planorbidae, Lymnaeidae and Physidae of Peru (Mollusca: Basommatophora). Memórias do Instituto Oswaldo Cruz 98: 767-771. https://doi.org/10.1590/S0074-02762003000600010

PARAENSE W. L., DESLANDES N. 1955a. Observations on the morphology of Australorbis nigricans. Memórias do Instituto Oswaldo Cruz 53: 121-134. https://doi.org/10.1590/S0074-02761955000100012

PARAENSE W. L., Deslandes N. 1955b. Observations on the morphology of Australorbis glabratus. Memórias do Instituto Oswaldo Cruz 53: 87-103. https://doi.org/10.1590/S0074-02761955000100009

PARAENSE W. L., PONTIER J. P. 2003. Physa acuta Draparnaud, 1805 (Gastropoda: Physidae): a study of topotypic specimens. Memórias do Instituto Oswaldo Cruz 98: 513-517. https://doi.org/10.1590/S0074-02762003000400016

PONDER W. F. 1988. The truncatelloidean (= rissoacean) radiation: a preliminary phylogeny. Malacological Review, supplement 4: 129-166.

SAlAmUni R., SAlAmuni E., ROCHA L. A., ROCHA A. L. 2001. Parque Nacional do Iguaçu, PR. Cataratas de fama mundial. In: SCHOBbenHAUS C., CAMPOS D. A., Queiroz E. T., Winge M., Berbert-Born M. L. C. (eds). Sítios geolóricos e paleontológicos do Brasil. DNPM. Rio de Janeiro 11: 313-321.

SCOTT M. I. H. 1958. Nueva especie de Chilina del norte Argentino. Neotropica 4: 26-27.

Sideman W. A. JR, Rodrick G. E., PARAEnSE W. L., VARGAS G. M. 1985. Biomphalaria straminea and other planorbids in the Dominican Republic. Memórias do Instituto Oswaldo Cruz 80: 453-456. https://doi.org/10.1590/S0074-02761985000400012

SILVA M. C. P. DA 2003. Hydrobiidae (Gastropoda, Neotaenioglossa, Rissooidea) da planície costeira do Rio Grande do Sul, Brasil. PhD Thesis Universidade Federal do Rio Grande do Sul. Porto Alegre, 382 pp. 
SiLVA M. C. P. DA, VeITENHEIMER-MENDES I. L. 2004. Nova espécie de Heleobia (Rissooidea, Hydrobiidae) da planície costeira do sul do Brasil. Iheringia, Série Zoologia 94: 89-94. https://doi.org/10.1590/S0073-47212004000100016

SiMONE L. R. L. 2006a. Land and freshwater mollusks of Brazil. EGB Fapesp., São Paulo.

SiMONE L. R. L. 2006b. Accounts on the phylogeny of the Rissooidea (=Hydrobioidea) and Littorinoidea, based on some American representatives, as base for a future taxonomic revaluation (Mollusca, Caenogastropoda). Strombus 13: 18-26.

SIMONE L. R. L. 2011. Phylogeny of the Caenogastropoda (Mollusca), based on comparative morphology. Arquivos de Zoologia 42: 161-323. https://doi.org/10.11606/issn.2176-7793.v42i4p161-323

SimONE L. R. L., BUNiOTO T. C., AVELAR W. E. P., HAYASHI C. 2012. Morphology and biological aspects of Gundlachia ticada from S. E. Brazil. Archiv für Molluskenkunde 141: 21-30.

https://doi.org/10.1127/arch.moll/1869-0963/141/ 021-030

SimONE L. R. L., MORACCHIOLI N. 1994. Hydrobiidae (Gastropoda: Hydrobioidea) from the Ribeira Valley,
S. E. Brazil, with descriptions of two new cavernicolous species. Journal of Molluscan Studies 60: 445-459. https://doi.org/10.1093/mollus/60.4.445

SimONE L. R. L., SEABRA M. I. G. L. 2017. Shell and body structure of the plesiomorphic pulmonae marine limpet Siphonaria pectinata (Linnaeus, 1758) from Portugal (Gastropoda: Heterobranchia: Siphonariidae). Folia Malacologica 25: 147-164. https://doi.org/10.12657/folmal.025.012

TAYLOR D. W. 2003. Introduction to Physidae (Gastropoda: Hygrophila); biogeography, classification, morphology. Revista de Biologia Tropical 51, supplement 1: 1-287.

VAZ J. F. 1979. Apontamentos sobre a anatomia macroscópica do sistema nervoso de Aplexa marmorata (Guilding, 1828) - (Basommatophora - Physidae). Anais do V Encontro dos Malacologistas Brasileiros. Publicações Avulsas da Fundação Zoobotânica 4: 55-67.

WoRMS. 2020. Chilinoidea Dall, 1870. World Register of Marine Species, Editorial Board. Available online at https://www.marinespecies.org/aphia.php? $\mathrm{p}=$ taxdetails\&id=489333 (accessed 1 April 2020).

Received: August 7th, 2020

Revised: January 15th, 2021

Accepted: February 1st, 2021

Published on-line: March 5th, 2021 